Mariyana Tsibranska-Kostova (Sofia)

\title{
Paulicians Between the Dogme and the Legend ${ }^{*}$
}

\section{General statement}

Of all medieval confessional deviations from the Orthodoxy called by the term 'heresies' the Bogomilism and the Paulicianism have the longest life in the Bulgarian cultural-historical memory. The reasons for the given state of matters in regards of every one of both, as close to each other, as self-dependent, are different, but the final result is the same. As concerns the Paulicianism, at first place it finds expression in a very strong nominative tradition, which survives despite the historical transformations of the former times medieval heretic movement ${ }^{1}$ into an ethno-confessional and linguistic-dialect community of the Bulgarian Paulicians Catholics as a product of the Modern Times and the Catholic propaganda in the Bulgarian lands from the beginning of the $17^{\text {th }}$ century ${ }^{2}$. If we paraphrase

\footnotetext{
* This article has been written under the research project Dualist Heresies in the History of South-East Europe $\left(9^{\text {th }}-15^{\text {th }}\right.$ centuries), financed by the National Science Centre (Poland). Decision number: 2016/22/M/HS3/00212.
}

${ }^{1}$ Because of the immense scope of the accumulated literature, here we will refer only to fundamental and quoted bibliographic unities: Petrus Siculus, Historia Manichaeorum, [in:] PG, vol. CIV, col. 1239-1304; Petrus Siculus, Sermo I-II adversus Manichaeos, [in:] PG, vol. CIV, col. 1305-1346; Pнотіus, Contra Manichaeos, [in:] PG, vol. CII, col. 15-264; Р.М. БАРтИкян, Петр Сицилийски и его "История павликиан", ВB 43.18, 1961, p. 323-358; N.S. Garsoian, The Paulician Heresy. A Study of the Origin and Development of Paulicianism in Armenia and the Eastern Provinces of the Byzantine Empire, Hague-Paris 1967; P. Lemerle, L'Histoire des Pauliciens d'Asie Mineure d'après les sources grecques, TM 5, 1973, p. 1-144; Christian Dualist Heresies in the Byzantine World c. 650 c. 1450, ed. J. Hamilton, B. Hamilton, Y. Stoyanov, Manchester 1998, especially: The Paulicians, p. 5-25; К. Гечева, Богомилството и неговото отражение в средновековна християнска Европа. Библиография, София 2007, especially: Манихейство, p. 93-100; Павликянство, p. 100-106; Średniowieczne herezje dualistyczne na Bałkanach. Źródła słowiańskie, ed. G. Minczew, M. SкоwroNEK, J.M. Wolski, Łódź 2015 [= SeCer, 1].

${ }^{2}$ E. FermendžIn, Acta Bulgariae Ecclesiastica. Ab a. 1565 usque ad a. 1799, Zagrebiae 1887; Л. Милетич, Нашите павликяни, СНУНК 19, 1903; М. Йовков, Павликяни и павликянски селища в българските земи XV-XVIII в., София 1991; Документи за католическата дейност през XVII в., София 1993; Н. НЕДЕлчев, Диалект на българите католици (северен павликянски говор), Велико ТърНово 1994; Е. ВРАЙКОва-ГеНОвА, Белене. Говор На павликянИте католици, Плевен 2003; M. Walczak-МıкоєајсZaкowa, Piśmiennictwo katolickie w Bułgarii, Poznań 2004; 
the title of the eminent explorer of the European dualism J. Duvernoy, and change the original relation in his article Les noms et la chose $e^{3}$, the case in point is one and the same term in which one puts different content, but it keeps alive precisely because it has what to name, that is to say because of the constant presence of the Paulicians and the Paulicianism in Bulgarian cultural-historical context. From the contemporary point of view, over the terms 'Paulicianism' and 'Paulicians' some stable meanings, word-uses and colocative unities have been shaped:

1. Medieval heretics, followers of the dualistic teaching, which came to birth in Western Armenia in the $7^{\text {th }}$ century, and consequently, during the $8^{\text {th }}-10^{\text {th }}$ centuries, spread in Asia Minor, Syria, Byzantium, and Bulgaria (derivative 'Paulician heresy').

2. Denomination of a part of Bulgarian ethnos, which adopted Catholicism as a result of the Contra reformation, the Council of Trent (1545-1563), the subsequent purposeful aspirations of the Roman Catholic Church to expand its influence in the Balkans, and especially after the Franciscan order's mission in the Bulgarian lands head by Petar Solinat in 1595 (derivatives 'Paulician dialect', 'Paulican literature', including a rich nominative tradition of toponymy in the historically raised villages of Paulicianism in North Bulgaria, the region of Nikopol, Chiprovtsi, and around Plovdiv $)^{4}$. In the initial period of proselytism, those Bulgarians still kept their old beliefs of dualist heretics, which, in conditions of the Ottoman domination on the Balkans, were mixed with folk style practices and superstitions because of low educational and social level. They occurred to be the suitable target for the Catholic missionaries being isolated from their Orthodox compatriots and the Greek clergy as Schismatics. Long time before L. Miletich had titled his fundamental work Our Paulicians, the "bishop of Great Bulgaria" Filip Stanislavov, himself Paulikyanich by second name, used the same expression: nostri Paulinisti, Catholici Bulgariae u Pauliani; other definitions about them were also Scismatici quali sono ostonatissimi e difficilissimi a ridursi all abedienza della Santa Romana Chiesa $a^{5}$.

М. Димитрова, Книжнината на българите католици, [in:] История на българската средновековна титература, ed. А. Милтенова et al., София 2008, p. 744-752; Л. ГеоргиЕв, Бблгарите католици в Трансилвания и Банат XVIII-първата половина на XIX, София 2010; Д. РАдевА, Павликяни и павликянство в бблгарските земи. Архетип и повторения VII-XVII в., София 2015.

${ }^{3}$ J. Duvernoy, Les noms et la chose, SlOc 16, 2003, p. 189-198.

${ }^{4}$ К. Станчев, Литературата на българите католици през XVII и XVIII в. и преходът от Средновековие към Възраждане, ЛМ 3, 1981, р. 3-11; М. АБАджиЕвА, Езикбт на павликянската Книжнина от XVIII в., БЕ 40, 2013, Supplement, p. 262-274; И. ЗЛАТАНОВ, П. ЛЕгурСКА, ОбреченИ на малцинство, Дз 2.4, 2014 - where authors point more then 26 oikonymes from the same motivating roof.

${ }^{5}$ Документи..., p. 27, 42. 
3. Derivatives in the dialects which were realized deviations from the true faith, as for instance павликянче 'non-baptized child', together with поганче, еврейче, дяволче, некргстче and others, developing the feature 'unclean', 'non-Christian', 'from other faith', or the famous popular formula in the rite of baptism dadoxme ни го павликянче, на ви го сега христиенче (you gave the child to us Paulician, here we return the child to you Christian) ${ }^{6}$. The dialects know the word naвльo as a different appellative to Catholic, the second meaning of the term. In Ottoman times, the term Paulicians was charged with keeping alive the generic consciousness and preserving the community. However, surmounting the initial proselytism, the confessional group of Bulgarian Paulicians stopped self-identifying with this term, because they estimated it already obsolete and pejorative, and replaced it with the more suitable Catholics.

The beginning of this long lasting continuum has been started in the Medieval Ages. It is the reason for the variation of the written sources about Paulicians from historical or strict dogmatic writings of significant Byzantine Church authorities, some works of whom have been translated in Slavonic, to original, or revised and compiled in Bulgarian environment popular and legendary texts. In the present article, we shall try to compare the way of how Paulicians were described in both types of sources by using for this purpose the approach of the linguistic and culturological conceptualization of the alterity. Our aim is motivated by the commonly acknowledged fact that in the basic anthropological opposition 'one's own - other' in its social prospective the confessional sign is a key position of comparison. Our concrete tasks will be, by means of linguistic analysis, to reach some essential dogmatic issues in the Paulician doctrine, and to focalize on the perception models towards Paulicians with their tangible semantic codes according to the specifies of the Medieval world view. The two chosen texts our analysis will be based on, are as follows:

1. The legendary narrative Sermon about how the Paulicians have been conceived (cetera: $S$ ). It rejoices at live scholar interest and has already a reliable archeographic record with eight copies known insofar ${ }^{7}$. In their titles, three of them carry out

\footnotetext{
${ }^{6}$ М. КитАновА, “Чуждите” деца в българската култура и език, БЕ 61.3, 2014, p. 19-32; data base from the Archive of the Department of dialectology and linguistic geography in the Institute for Bulgarian Language, Bulgarian Academy of Sciences.

${ }^{7}$ Й. ИвАнов, Произход на павликяните според два български рбкописа, [in:] Избрани произведения, vol. I, София 1992, p. 111-123; А. МилтеновА, Разобличението на дявола-граматик (към историята на старобългарската легенда за произхода на павликяните), [in:] Човек и време. Сборник с научни изследвания в памет на Сабина Беляева, еd. Р. ДАмяновА, Е. ТрАйковА, София 1997, p. 287-294; ЕАDЕм, Отново за разказа за произхода на павликяните, BMd 6, 2015, p. 233-240; К. СТАнчев, Павликяните - ученици на дявола. Бележки относно финала на апокрифния разказ за произхода на павликяните, [in:] Vis et Sapientia. Studia in honorem Anisavae Miltenova, ed. A. Angusheva, M. Dimitrova et al., София 2016, p. 761-768; Średniowieczne herezje
} 
John Chrysostom's name to whom refers the typical Bulgarian location of the plot nearby the fortress of Petrich and the area of Bachkovo monastery - one of the centers of fight against the Armenian-Paulician heresy in Thrace, where as early as the $8^{\text {th }}$ century the Byzantine emperors, particularly John I Tzimiskes (969-976) in 975 settled Paulicians and Armenians tondrakites, considered to be also Paulicians, in the region of Philipopolis, and in this way fostered the Paulician presence in the Balkans ${ }^{8}$. One supposes that the legend occurred among the cultivated low clergy from the region soon after the establishment of Bachkovo monastery 'St. Theotokos' from Gregory Pakourianos ( $\dagger 1086)$, that is to say not later than the beginning of the $12^{\text {th }}$ century. One unique prototype with several revision changes underlies at the base of the overall text record. According to its most persistent contemporary scholar A. Miltenova the work takes place among the most valuable popular and legendary narrative sources about the Paulicianism and the attitude towards it in Bulgarian environment. It could be also added that the Sermon is a testimony from the early period of the Byzantine domination, and it is not excluded its appearance to be stimulated by real historical events as the Paulician rebellion from 1074 nearby Philipopolis?.

2. The second text is strictly dogmatic one, and has never been studied in its Slavonic translation for the time being. It is about the $24^{\text {th }}$ title of Panoplia Dogmatica

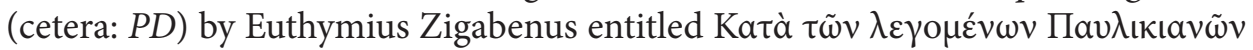

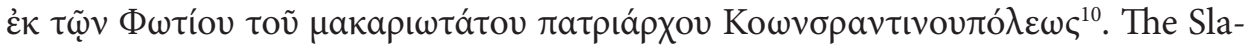
vonic translation of this "anti-heretic encyclopedia" from the reign of emperor Alexius I Comnenus (1081-1118), commissioned personally by him and compiled as a mature work of the great hereciologist about 1104-1118, raises a series of con-

dualistyczne na Bałkanach..., p. 225-231 - with reedition of the original Slavonic text and translation in Polish language. In modern Bulgarian translation the Sermon is inserted among the Bulgarian stories, narratives and revisions of Greek originals in: Д. ПеткановА, Народното четиво през XVIXVIII в., София 1990, p. 302-303; Д. РАДЕвА, Павликяни... - photo type reproduction of Adzhar copy according to Ivanov's edition with new Bulgarian translation by M. SpAsova, p. 521-534.

${ }^{8}$ Christian Dualist Heresies..., p. 23; Р.М. БАртикян, Византийская, армянская и болгарская легенды о происхождении павликиан и их историческая основа, Bbg 6, 1980, p. 61.

9 Д. РАДЕвА, Павликяни..., p. 198.

${ }^{10}$ Euthymius Zigabenos, Panoplia Dogmatica, [in:] PG, vol. CXXX, col. 1189-1243; J. Wickert, Die Panoplia Dogmatica des Euthymios Zigabenos, Berlin 1910; M. ANGold, Church and Society in Byzantium under the Komnenoi, 1081-1261, Cambridge 2000, p. 45-72; A. Rigo, La Panoplia Dogmatica d'Euthymios Zygabenos. Savoir Encyclopédique et les Hérésies du Présent, [in:] Papers presented at the $19^{\text {th }}$ Annual Theological Conference of St. Tikhon's Orthodox University, Moscow 2008; IDEM, La panoplie dogmatique d'Euthyme Zigabène: les Pères de l'Église, l'empereur et les hérésies du present, [in:] Byzantine theologians. The systematization of their own doctrine and their perception of foreign doctrines, ed. A. Rigo, P. Ermilov, Rome 2009, p. 19-32; N. Miladinova, Panoplia Dogmatike - a study on the antiheretical anthology of Euthimios Zigabenos in the Post-Byzantine Period, Leuven-Budapest 2010; M. Berke, An annotated edition of Eyrhimios Zigabenos, Panoplia Dogmatike, Chapters 23-28, Belfast 2011. 
troversial questions, and still has an unclear destiny. Remarkable fact is that the fifth most important anti-heretic titles, namely against the iconoclasts, the Armenians, the Paulicians, the Massalians, and the Bogomils (in the Greek original under numeration 22, 23, 24, 26, and 27 from the second book of the Panoplia), in Slavonic translation have been preserved in a unique copy: in manuscript from the Library of the Romanian Academy of Sciences in Bucharest BAR Ms.slav. 296 from the first quarter of the $15^{\text {th }}$ century (1410-1420) - the first four mentioned titles, but with different numeration from $19^{\text {th }}$ to the $22^{\text {th }}$ titles; the title against the Bogomils - in the manuscript from the National Scientific Library in Odessa, Ukraine, ОГНБ 1/108. The same title against the Bogomils is absent from the manuscript from the Romanian repository, because the manuscript itself is not entirely preserved, and ends on $\mathrm{f}$. 330v with the title against Massalians unachieved. The title against Paulicians here comprises folia $280 \mathrm{r}-322 \mathrm{v}^{11}$. Some scholars examine the "Bucharest" and the "Odessa" parts of the Slavonic Panoplia as two text portions of one and the same manuscript body with one and the same copyist, who has been identified with the Bulgarian Gerasim, famous by copying with his recognizable handwriting important written monuments of patriarch Euthymius' Literary School, but the alternative hypothesis that the "Bucharest" part of the Slavonic Panoplia represents an autograph of anonymous translator, who translated it on Mouth Athos, is not to be neglected easily ${ }^{12}$. This means that the chronology of the translation in the both opinions still keeps to be divided between the end of the $14^{\text {th }}$ - the first two decades of the $15^{\text {th }}$ centuries, with all questions resulting from about the place, the translator/translators, the existence or non-existence of a presumed official commission by concrete Church or secular power. Insofar, the two manuscripts with different location are the only ones witnesses about the Slavonic translation of the mentioned anti-heretic titles, and the scholarly perspectives in their regards are complexes. The issues on the early $P D$ Slavonic translation, in general, seem complicate enough too. Despite these matters will not be a special focus of attention, we estimate the partial publication and analysis

\footnotetext{
${ }^{11}$ P.P. Panaitescu, Manuscrisele slave din Biblioteca Academiei RPR, vol. I, București 1959, p. 395396. The peculiarities of this textual segmentation are to be discussed further in the article.

${ }^{12}$ К. Иванова, О славянском переводе Паноплии догматики Евфимия Зигавина, [in:] Исследования по древней и новой титературе, Ленинград 1987, р. 101-105; Н. ГАГовА, Един вероятен преводачески автограф от пьрвата четвърт на XV в. (Още веднъж за ранния славянски превод на "Догматическо всеоръжие" на Евтимий Зигавин), Pbg 25.1, 2001, p. 79-94; ЕADEм, Поръчвал ти е деспот Стефан Лазаревич превода на “Догматическо всеоръжие” от Евтимий Зигавин, [in:] ЕADEм, Владетели и книги. Участието на южнославянския владетел в производството и употребата на книги през Средновековието (IX-XV в.): рецепиията на византийския модел, София 2010, p. 130-140. Indirectly, some matters about the Slavonic translation of PD have been touched in other publications, as for example: Я.М. Волски, Богомилите и светлината на Житието на св. Иларион Мъгленски от патриарх Евтимий Търновски, Pbg 37.4, 2013, p. 74-81; IDEM, Autoproscoptae, Bogomils and Massalians in the $14^{\text {th }}$ Century Bulgaria, SCer 4, 2014, p. 233-244.
} 
of one of the most voluminous anti-heretic titles of the Slavonic $P D$, undertaken for the first time, very useful for further and absolute obligatory researches upon, which, hopefully, will not be late to appear.

\section{Semantic codes}

1. For every medieval text is of great importance to be credited with a high authority. The pseudo-attribution to John Chrysostom in some copies of $S$ is an approved way of generating prestige to a text from the "law" tradition. On opposite, as still visible in its title, $P D$ sticks to one of the most authoritative anti-Paulician Byzantine works all over the Medieval Age. Patriarch Photius's ( $† 893)$ work Contra Manichaeos served as base for Zigabenus's compilation, which is acknowledged

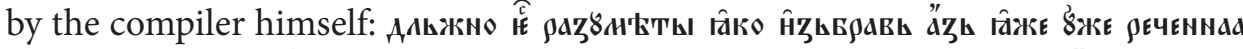

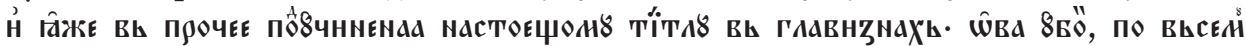
сьврь⿳⺈⿴囗十

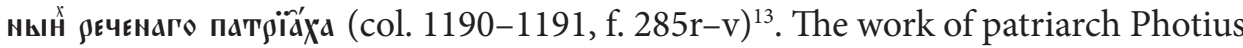
is even more valuable because the author reproduced some first hand testimonies from Peter of Sicily, who in $869-870$ had been commissioned by emperor Basil I as ambassador to Chrysocheir, leader of the Paulicians in their independent state near the Byzantine-Arab frontier. Since Peter of Sicily's writing is known according to only one $11^{\text {th }}$-century Greek copy, and this of patriarch Photius according to 10 Greek copies, but no Slavonic recorded, what has been included in $P D$ practically gave to both of them a new life, especially in regard with the historical and the dogmatic knowledge about Paulicians in Slavic medieval milieu ${ }^{14}$. However, in the title in question, one considers patriarch Photius's base in Zigabenus's work so much extended with secondary additional material about the Paulician beliefs, that its cohesion was damaged, and consequently the entire title was not properly used as source about the Paulicianism ${ }^{15}$.

2. Onomastic material. The relationship between onymy and heresy is a firstdegree code, because that is exactly by the notion and the appellation, the denotate and the designate, the denominating and the denominated enter in close relation.

\footnotetext{
${ }^{13}$ From here onwards, we shall mark the comparisons between Slavonic and Greek texts of PD following the official standard norms of $P G$ edition for the Greek text, and the folia in the Romanian manuscript BAR 296 for the Slavonic one. On the back cover, Ms. slav. BAR 296 brings information of having been counted 330 folia in 1898, all stamped with a seal. We shall designate folia according to this numbering.

${ }^{14}$ The most important Greek sources about Paulicianism are translated in French by authors team: Ch. Astruc, W. Conus-Wolska, J. Gouillard, P. Lemerle, I. Papachryssanthou, J. Paramelle, Les sources grecques pour l'histoire des Pauliciens d'Asie Mineure, TM 4, 1970 - among which the commencement of the quoted Photius's work. Christian Dualist Heresies..., p. 5-6.

${ }^{15}$ N. Garsoian, The Paulician Heresy..., p. 26-79; N. Miladinova, Panoplia Dogmatike..., p. 7.
} 
Onymic code comprises three primary positions: the name of the heresy; its founders, teachers and disciples, and the geographic area it comes to birth, and spreads.

a) Diverse theories try to explain the origin of the name 'Paulician' and its specific reference. $P D$ draws it from the double name of the two brothers Paul and John,

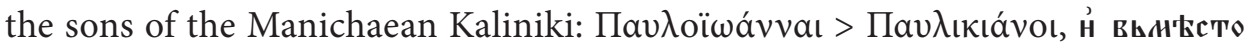

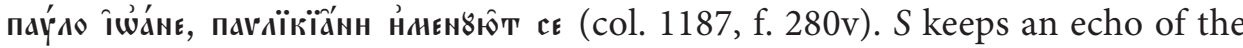
same denomination. Coming in the Bulgarian lands, the two devil's disciples Sabotin and Shutil take apostolic names Paul and John, and teach people to worship apostol Paul. The text concludes that the followers who adopted their law must be called Paulicians (according to different copies of $S$ ПавликиАне, Павличанє, Павликинє, павлик'внє). The relationship between the name of the heresy and the proper name Paul is out of doubt, having given birth to both popular and plausible scholarly etymologies. Because of the special respect to Saint Paul's Epistles among Paulicians, some etymological explanations specify that 'Paulicians' more accurately result from $\pi \alpha \tilde{u} \lambda ı \kappa ı<~ \Pi a \tilde{\lambda} \lambda o \varsigma$, as the Epistles had been called on the base of the personal name of their author ${ }^{16}$. According to other explanation, Paul of Samosata (precisely Arsamosata in Armenia), that is to say only one of the brothers, homonym of St. Paul, is to be in the base of the ontogenesis of nomination, but in fact, one deals with triple confusion of different historical personages with the name of Paul. The canonic sources clearly speak about Paulicianists, Paulicians, in essence, Trinitarian heresy, followers of Paul, bishop of Samosata in North Mesopotamia (260-268), whose connection with Paulicians dualists is not direct, but it often occurred medieval authors to merge them. The famous canonist Theodore Balsamon ( $\dagger$ after 1195) also mentions the fictional story of Kaliniki and her sons in his commentaries upon the Canon law legacy ${ }^{17}$. According to another third

\footnotetext{
${ }^{16}$ Български етимологичен речник, vol. IV, София 1995, p. 997.

${ }^{17}$ For those heretics see the $19^{\text {th }}$ canon of the First Ecumenical Council in Nicea from 325, Paulicians

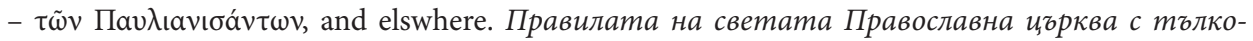
ванията им, еd. С. ЦАнКОв, И. СТЕФАНОВ, П. ЦАнЕв, vol. I, София 1912, p. 353-357. Theodore Balsamon's commentaries on the p. 355. The same heretics are mentioned in Slavonic kormchayas, including in the excerpts from the anti-heretic writings of Epiphanius of Cyprus and Timothy of Alexandria, for example in the Ilovica kormchaya from 1262, f. 352r-v: павлитанисте. єжє соүть па-

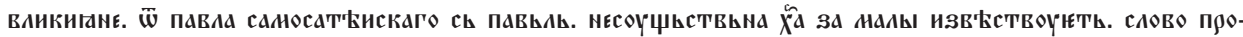

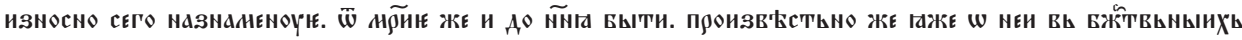

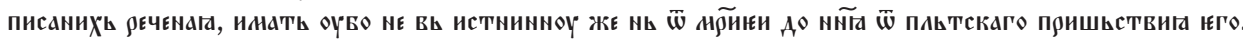

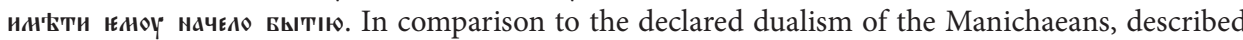

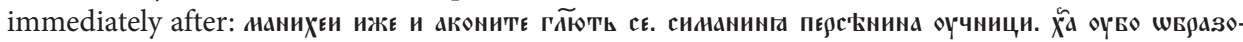

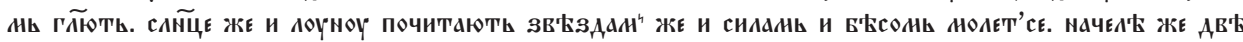
наоүчають зион же соүче и вйгон... The passages quoted following the photo type reproduction Законоправило или Номоканон светога Саве. Иловички препис 1262 г., еd. М. Петровић, Горњи Милановац 1991. The different meaning between Paulicianists and Paulicians, павлияне and павликяне, is recorded in Slavonic diachronic dictionaries on the base of diverse sources, for instance
} 
explanation 'Paulicians' derives from the Greek-made variant of the Armenian name Paulikeank, a derogative diminutive from Paul, literally "disciples of little Paul", presumably a later leader of Paulicians, who took them back in Armenia in the $11^{\text {th }}$ century ${ }^{18}$. Apparently, various phonetic and semantic associations leaded to this pluralistic interpretation. A frequent procedure in the law level non official and apocryphal literature is to oppose the real and the fictive in one and the same denomination, and to create an homonymy (by analogy, the mythic founder of the Latin heresy, Peter the Stammerer is an antipode of St. apostol Peter, as well as the mythic brother from the couple John-Paul is an opposite to St. Paul). In $S$, the analogic approach finds supplementary grounds by deriving the devil's name

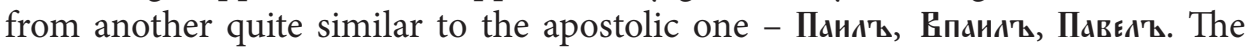
names Павлика, Пулика (Pavlika, Paulika) are the devil's names in the Armenian folklore $^{19}$. It is well known, however, that Paulicians, as the other dualistic heretics, especially the Bogomils and the Cathars, prefer to identify themselves simply as Christians.

b) Both analyzed texts lay upon the transmission of the primary code of nomination and a strong onomastic continuity, but due to their different nature, the texts differ in historical information and credibility. The rich onomastic material from $P D$ continues in a series of concrete names by use of which one describes exhaustively the first Paulician teachers and spiritual leaders, who accepted new names in purpose of imitating apostol Paul's disciples. The change of name, or the creation of a double name, are significant facts in the Christian paradigm, as they are a symbol of spiritual initiation. In both texts, however, the process of changing names functions with its enantiosemy, or the development of an opposite negative connotation versus the entirely positive biblically-shaped process of naming apostles. As a result, the renamed subjects are accused in false observation of the Holy Scriptures, insincerity and hypocrisy. By use of the verbs иненовати,

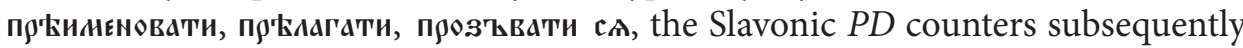
and in historical chronology the double names of the main Paulician leaders, by the efforts of whom the Paulicianism strengthened its position of teaching with its own dogma and relevant organization. Without its teachers and leaders every doctrine is doomed to failure and death. It is proved that thanks to Photius's work and its revival in Zigabenus's compilation Paulicianism stands out as the first heresy in chronological order to be the direct adherent and successor of the Manichaeism, which could explain the stereotypes of merging and identifying Bogomilism, Manichaeism, Massalianism, and Paulicianism during the whole medieval period. Patriarch Photius wrote in the $9^{\text {th }}$ century when Paulicians manifested them-

Словарь древнерусского языка, vol. XIV, Москва 1988, p. 112-113.

${ }^{18}$ P. Lemerle, L'Histoire des Pauliciens..., p. 52; Christian Dualist Heresies..., p. 7.

${ }^{19}$ Р.М. БАРтикян, Византийская, армянская и болгарская легенды..., p. 59. 
selves in war conflicts against the empire and proved to had deserved of not being underestimated force (likewise in Peter of Sicily who described the insurrection of Paulician ruler Chrysocheir and the Paulician state with capital Tefrice, which the Byzantine ambassador and writer visited personally; in Zigabenus's lifetime, more precisely in times the Greek $P D$ was presumably completed, about 1114, the Byzantine emperor Alexius I Comnenus leaded a successful military campaign against the Paulicians around Philippopolis, and even succeeded in converting some of them into the Orthodox faith $)^{20}$. For the Slavic studies of Paulicianism, the onomastic data base of $P D$ is without precedent in abundance of facts, because they reproduced Photius' grounds, which, in their turn, coincided in numerous points with Peter of Sicily's account ${ }^{21}$. The names of the Paulician leaders are as

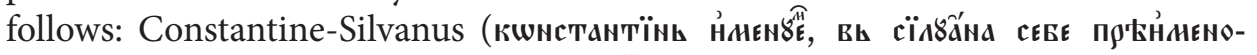

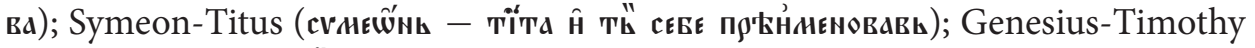

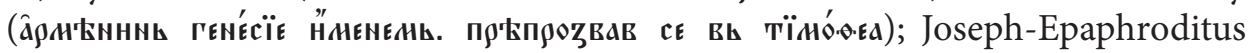

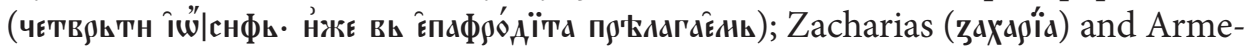
nian Vahan (вад́нь скврьнын -known also with the nickname 'The Fool') remained without a second name; finally Sergius- Tychicus, or in total seven "evils" in the

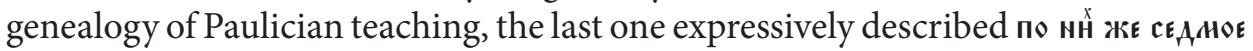

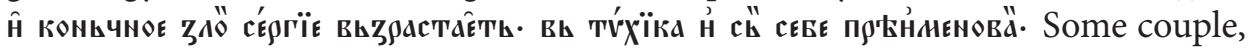
as this one of Sergius-Tychicus were closely connected with the names of heretic leaders, convicted until and on the Fourth Ecumenical Council of Chalcedon, 451 AD. The list of those heretics traditionally starts with Arius, Nestorius and famous monophysites, but includes Paul from Samosata and Lucopetrus as well, the last one declared teacher of Sergius, the alleged legendary founder of the arajavor fast (a preliminary fast from the pre-Lenten penitential cycle, held during the week between the Sunday of the Publican and Pharisee and the Sunday of the Prodigal Son), and a leader of the Bogomils-Phundagiagitae from the Byzantine theme Opsikion in northwestern Anatolia, Asia Minor, during the first half of the $11^{\text {th }}$ century, as stated by Euthymius of Peribleptos in his famous $11^{\text {th }}$-century Epistle based on authentic contemporary data ${ }^{22}$. Historically speaking, in some personali-

\footnotetext{
${ }^{20}$ N. Miladinova, Panoplia Dogmatike..., p. 4; Christian Dualist Heresies..., p. 24.

${ }^{21}$ In M. Berke (An annotated edition..., p. 46-47) the title is reedited under number 25, and with a new textual segmentation, in our opinion, easier for pointing out separated text blocs, and for their comprehension. In his History of Paulicians, Peter of Sicily counts up almost the same couples of names, some of which the author skillfully parodies. One of the famous examples is Titus's name

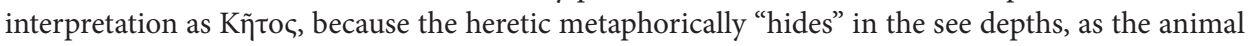
does, but surprises unexpectedly the sailors.

${ }^{22}$ G. Ficker, Die Phundagiagiten. Ein Beitrag zur Sektengeschichte des byzantinischen Mittelalters, Leipzig 1908, p. 165, 211-219; M. ANGold, Church and Society..., p. 467; J. Goulllard, L'hérésie dans l'Empire byzantin jusqu'au XII siècle, TM 1, 1965, p. 299-324; A. SHARF, Byzantine Orthodoxy and the "Preliminary fast" of the Armenians, [in:] Byzance. Hommage à André Stratos, vol. II, Théologie et Philologie, Athènes 1986, p. 669-670.
} 
ties, one alludes both to monophysites and to dualist heresy of Paulicianism. Name is a basic identification for one religious doctrine or another. That is way, recording names in the official Synodikon of Orthodoxy was already sufficient orientation mark to which of its parts a given name to be affiliated to - to the glorification or to the anathema ${ }^{23}$. From all mentioned Paulician leaders the name of ConstantineSilvanus from Mananalis in Armenia, who lived in times of emperor Constance II (641-668), is to be specially outlined, because he was thought to have established the Christian dualism, as distinct from the Zoroastrism and the Dualism of Persian Mani (216-277) $)^{24}$.

In $S$ 'the motif of renaming' is much more simplified and easy to decode for its double-step structure. The devil's disciples adopted new Christian names, so that the stereotype was kept by virtue of traditional view: every heresy is delusive; it seduces by apparent observation of the true Christianity, but there are irreconcilable contradictions between internal content and visible form. External signs are first-degree level of perception and could easily mislead. Renaming Sabotin and Shutil in Paul and John followed apostolic model with the difference that the second emblematic couple of names was deprived from its leadership. While in the spirit of dualism in $S$ the devil established a parallel world on his own, and communicated as equal with famous figures of the Christianity, as Basil the Great and John Chrysostom, that is namely from him all primer causes for the Paulician delusion originated. The names Sabotin and Shutil can be met in various transcriptions, most of which arisen during the natural changing in different milieu of copying as because of technical mechanic errors, as because of the associative processes of paronymia, paronomasia, popular etymology: Gатинъ, Gоувотинъ, Gановатия; Шоүтиль, Шоүтиа, Моүшин'ъ, Моүшоүнъ. There are controversial opinions whether they originated from Slavic motivating roots (A. Miltenova

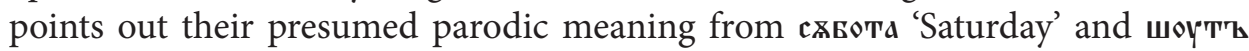
'jester', but we allows us to precise that the second one must be rather understood in the meaning of 'fool, foolish', metaphorically 'insane, madman', not 'without horn'), or they derive from Armenian names Smbat, Sumbat, Sheti, Shatila and other variants, encountered in historical works, popular legends and even in the Persian mythology ${ }^{25}$. Both hypotheses reconcile to one another if one supposes

\footnotetext{
${ }^{23}$ И. Божилов, А. ТотомановА, И. Билярски, Борилов Синодик. Издание и превод, София 2010, p. 308, 329 - where one can read some of the above-mentioned names. Exhaustive identification and most contemporary-sourced historical information about is to be found in the quoted work: Christian Dualist Heresies..., p. 10-19.

${ }^{24}$ On the given issues we shall refer again to: Christian Dualist Heresies..., p. 1-4, 8 - where this distinction is pointed in a very accessible but not less scholarly exhaustive prospective. The name of Constantine-Silvanus could become familiar to Slav interpretators and men of letters according to the mention in George Hamartolus's Chronicle in its Slavonic translation, vide: Словарь древнерусского языка, vol. VII, Москва 1980, р. 112.

${ }^{25}$ Р.М. БАРтикян, Византийская, армянская и болгарская легенды..., p. 61.
} 
that primary Armenian names spread in Armenian legends, once come into contact zone of the two ethnic groups, namely Slavs Bulgarians and Armenian diaspora, could be reconsidered in Slavic prospective. It should be noticed that this approach was also of great frequency in the expressive arsenal of the low-level and apocryphal literature ${ }^{26}$. We could not leave without attention one echo from obviously popular legendary impact over a song from Sofia region which surprisingly refers to derivates from the two key names in the Paulician legend. The song in question addresses to four anonymous saints the following words: като ŭuдете код милого Бога, споменете за йоанинска земя, за земя павликянска (when you go to our cherished God, mention him the land of John, the land of Paul - DA).

c) The recorded toponymes in the Slavonic version of $P D$ and $S$ testify how some space-shaping and locating mechanism had been put into practice. Accordingly to both texts, one deals with the Paulicianism spread in a precise geographic area. Toponymes are not of less importance in achieving some polemic and accusatory objectives. In $P D$, the high education and knowledge of the author come out from the exact description of the sixth Paulician churches, everyone with its relevant heretic congregation and leader, together with their main centers, villages and fortresses alike. One should remind the famous $\mathrm{H}$. Delehaye's conclusion that the legend obligatory possesses une attache historique ou topographique, because of its functional validity to the hagiographic model for the saint and its opposite register for unmasking heretic, as both sanctity and its antipode come to birth in a given $\operatorname{space}^{27}$. The toponymic data increase the level of historical knowledge. $P D$ tells how territories of Paulician influence had been organized into Paulician churches on the example of Jesus Christ's apostles in the following religious centers in Armenia, Pontius region in Asia Minor, Phanaroia in Byzantine Anatolia: Paulician church of Macedonia at Cibossa; this one of Achaia at Mananalis nearby Arsamosata in Armenia; Paulician church in Philippi; Laodicean church in Enargan; of Ephesius in the town Mopsuet in Cilicia, Asia Minor, and Colossean Church in Kanohorites, or Konohorion. The church names do not correspond to a real location, but follow important local points of St. Paul's missionary journey. This informational segment from the Slavonic translation follows literally the Greek original of $P D$.

In $S$, narrative plots brought together into вльгарскаға зенла (the Bulgarian

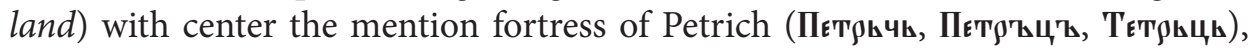
where the devil disciples came from Cappadocia. The 'Bulgarian land' was the territory of the subsequent story development with several controversial moments

\footnotetext{
${ }^{26}$ А. Милтенова, Разобличението на дявола-граматик...; ЕАдем, Отново за разказа... - special focus on scholarly opinions of R. BARTIKYAN, K. UZBASHYAN and others. P.М. БАРТИКян, Византийская, армянская и болгарская легенды..., p. 57-62; Д. РАдевА, Павликяни..., p. 20, 216-251. ${ }^{27}$ H. Delehaye, Les légendes hagiographiques, Paris ${ }^{2}$ 1906, p. 6.
} 
having allowed various interpretation among scholars. Weather the story told about John Chrysostom's arrival in 'Bulgarian land' from Constantinople, or the disciples of the devil were taken to him in Constantinople ${ }^{28}$ ?

3. Semantic code 'the heretic teaching, the heretic philosophy, нхдрхванию'.

a) The first substantial difference between the two sources is the lack of every hint of reference to Manichaeism as genetic base for Paulicianism in $S$. The relations with the dualistic marks of Paulician beliefs are only sub textual and allegoric. For $S$ more important is to draw their ontogenesis directly from the devil, from the Evil in itself. In opposition, $P D$ proclaims Manichaeism main ideological base for

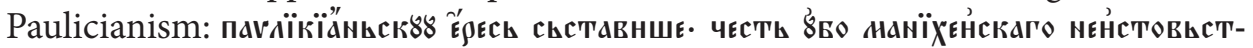
ва $\mathfrak{c} 8$ \& 8 . The same idea is not only repeatedly outlined at various semantic levels, but is accompanied by expressive epithets of total negation and denial. From the very beginning, $P D$ narrative reproduces the core of the Byzantine legend for the Paulicianism, in which the linking branch between both heresies is the mother Kaliniki who had drunk the mire of the Manichaean heresy: жєма жє н'大каd кал-

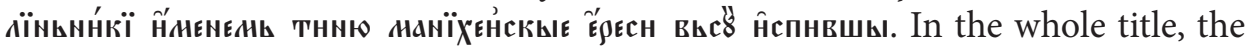
name of Mani and derivates from are in frequent use multiple times. The text declares that parallels with doctrinal axioms of dualism could be found in other

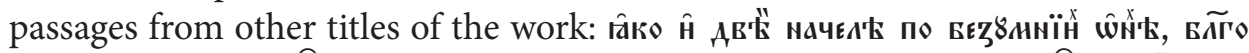

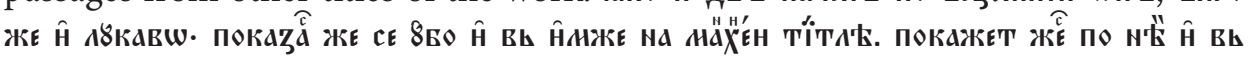

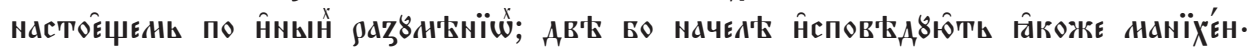

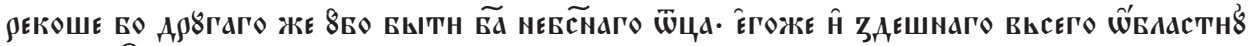

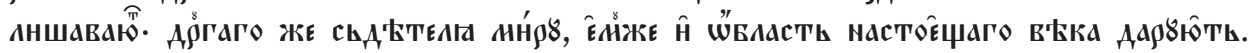
The main sign of the absolute dualism of Paulicians is the belief of two principles and the idea that the celestial father God has not power over the present material world but will have over the coming. The dualistic motivation is confirmed by $P D$ structure in which the first book from the two-volume treatise describes 16 heresies from the past, putting Mani and Manichaeism immediately after Jews and Symeon Magus of Samarea, regarded as founder and prime source of all heresies. At the same time, $P D$ leans on basic Biblical quotations, references and dictums with general validity to summarize the anti-heretic attitude in surviving

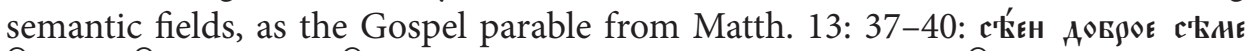

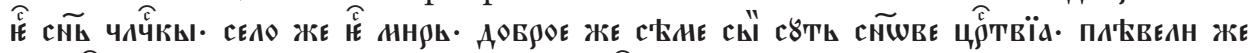

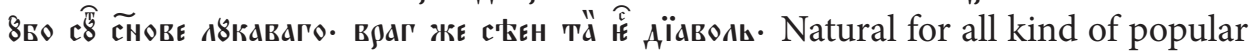
literature, the opposition between good and evil is basic for the studied legendary narrative too.

\footnotetext{
${ }^{28} \mathrm{~K}$. Stanchev draws a special attention to the possible interpretations of this passage accordingly to copies' testimonies. К. СтАнчев, Павликяните..., p. 767.
} 
The genealogic relationship between Manichaeism and Paulicianism is drawn on the level of ideological axiom, although $P D$ narrative refers to dogmatic disputes and heterodoxies inside Paulicianism, denial of Mani and veneration of the Paulician teachers as Jesus' apostles and $\delta ı \delta a ́ \sigma \kappa a \lambda o$. It turned into reason for politic courses the Byzantine central power had undertaken as early as the Paulicianism came to birth in the mid- $7^{\text {th }}$ century and onwards, by promulgation of civil laws and procedures against the heresy of Manichaeans, which consequently had been applied to Paulician heresy, treating it as Neomanichaeism. Most eloquent examples were the Ecloga of Byzantine emperors iconoclast Leo III Isaurian (717-741) and his co-ruler Constantine V Copronymus (720-740; emperor from 741 to 775), and later, about 870-879, the Procheiros nomos of emperor Basil I Macedonian and his sons Constantine ( $†$ 879) and Leo, the future emperor Leo VI the Wise (886-912). Both provided the death penalty for crimes against the Christian faith. In times of Basil I, who led successful war against Paulicians and subjected of their territories, special repressions were applied upon Manichaeans and Donatists. Procheiros nomos punished to death by sward former Christians turned into Manichaean heresy no matter of their social position and dignity; the same punishment as prevention was applied to all who knew about but did not bring information to the authorities. Social stigma laid upon Manichaeans even after someone's death, and his heirs, except children, even though Orthodox, were deprived of legacy in favor of the state treasure ${ }^{29}$.

b) The semantic code 'teaching through teachers and books' deserves some special attention being present in both texts but in a different way. In $S$, it is essential motive. The whole story begins with devil's transformation into grammarian, wise men with as beautiful appearance as nice the writing he produced looked like. The beauty of letters, in this case, signifies wisdom of mind too. In the prospective of medieval Slavonic lexis, some words, adjectives in particular, belong to both esthetic and ethic sphere of reference ${ }^{30}$. But in the logic of the plot and its rebuking line, the apparent occurs to be delusive, likewise the books diabolic. As early as the first apocrypha appeared, for instance King Abgar's Letter to Jesus, 'Written Word' was perceived emanation of Logos, and was credited by stronger and more durable power. In accordance, the heretic writing with function of dogma, teaching, should be denied entirely and forever. It was not hazardous in $S$ John Chrysostom to have recognized evil-intended nature merely by looking at the written text/letter sent to him much before he saw the face, because every act, ordered and magnificent, does

\footnotetext{
${ }^{29}$ I. Zepos, P. Zepos, Jus Graecoromanum, vol. 2, Leges imperatorum Isaurorum et Macedonum, Athen 1931 [= Aalen 1962], p. 219. The Serbian Ilovica kormchaya from 1262, when the Slavonic translation of the whole Procheiros nomos appeared, kept all those juridical regulations.

${ }^{30}$ Т.И. ВЕндина, Средневековый человек в зеркале старославянского языка, Москва 2012, р. 91.
} 
not come from Man, but from Devil, as stated in the legend ${ }^{31}$. Therefore, the final of $S$, already located in the Bulgarian land, reminds once again that, as in the very beginning, when the devil created writings, his serves, renamed but not changed by nature started teaching people with books, namely to spread their dogma and beliefs. Several variants in $S$-copies allowed to shape the so called Paulician literacy

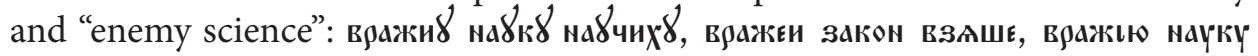
үзАли и писнио

$P D$ englobes detailed information about the development of the heretic movement by organizing meetings, or 'Paulician councils', mostly in the meaning of sect-participant assembly, intended to choose apostles, discussing dogma or some wavelengths of heterodoxy and heteropraxy. Frequent uses of words and

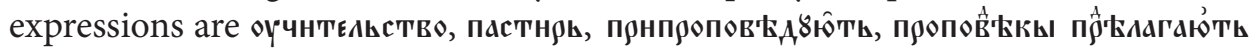
and so on. It is to outline that Zigabenus's encyclopedia of anti-heretic knowledge sets equally out the second more plausible and non-legendary version about the real dogmatic start of Paulicianism with its first scholarly acknowledged founder Constantine Silvanus, official leader of the sect who, in spite of being elected by Paulician assembly, kept his dogmatic revelations in secret. It is not difficult to recognize the motive 'secret heretic dogma' among other topoi in the overall anti-heretic literature: А

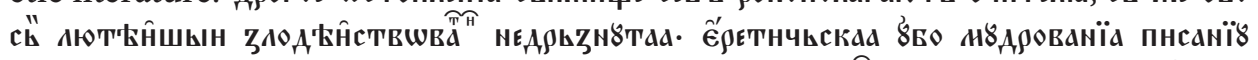

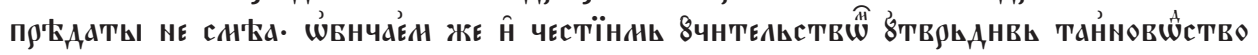
вавшыня ск Арьжатн.

c) We reach now the semantic code 'signs of Paulician dogma', as expected, truly and exhaustively present in $P D$. In $S$, some allusions for appear, but in conformity with the narrative objectives, they are not set apart in a polemic block bur rather interlace into the plot. The episode in the church during the liturgy on which John Chrysostom invited the devil to unmask him, shows gradually its self-destruction (shattered in pieces) by force of Christian formula and rituals Paulicians do not respect. The text implies the following practices: unacceptance of the church oblations, denial of the Theotokos and the sacrament of liturgy, as the pronunciation of the name of God has a death effect upon the devil. This is a clear allusion to dualism. Very interesting passage is the final of $S$ claiming that John Chrysostom

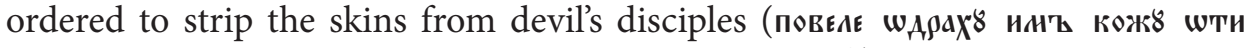

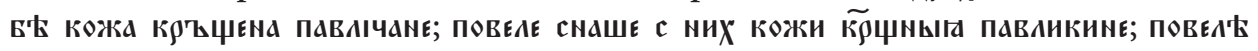
шдирати кожи их понєжє Б'Еш8 кожи их кбестни - and other variants). Paulicians thought this act had made them martyrs and authorized them to take Christian apostle's names, but the text concluded that all this was for the sake of their enemy law and teaching. K. Stanchev has wright to outline two elements in mutual connection: the fact that in the final story, in Cappadocia, devil's books were burn,

\footnotetext{
${ }^{31}$ Д. ПЕтКАНОвА, Народното четиво..., p. 303 - undoubted dualistic allusion.

${ }^{32}$ К. СТАнчев, Павликяните..., р. 767.
} 
but his disciples received mercy as Christian sons; the second episode implied the stripping off the skins because once baptized, they should be treated apostates. Every heretic is a wolf in a skin of sheep. The very metaphor of changing, or taking skin is typical and wide-spread in the anti-heretic polemic, including in concrete accusations to Paulicians ${ }^{33}$. At the same time, we should remind the motive of stripping the skin in Peter of Sicily's narrative in regard with Mani, who suffered identical punishment accordingly to the Persian customer law: his body was thrown away to beasts, his skin hang down as a sack ${ }^{34}$. From one side, it seems to us that $S$ keeps some reminiscences from historically controversial attitude to Paulicians during different periods, as from their strong claims to be called true Christians by wright. Paulicians were as persecuted heretics as rehabilitated Christians from the central Byzantine power. As early as the $8^{\text {th }}$ century, in Leo III's reign (717-741), the process in 730 in Constantinople against the already mentioned Timothy was initiated not because of iconoclast intentions, as Paulicians were strongly opposed to all religious images, but rather aimed at examining his loyalty of provincial heretic leader ${ }^{35}$. The process ended by his rehabilitation as Orthodox given to him directly from the then Byzantine patriarch. The heretic leader gained credit of trust because he adroitly succeeded in putting into operation allegoric perceptions of Christian dogma. Later, as it was referred to Alexius I Comnenus, other Byzantine emperors had also success in converting Paulicians to Orthodoxy. On the other hand, the possible lines of interpretation by analogy between historical setting and legendary fabula could not be neglected because the legend has already been a complex amalgam of fiction and polyvalent semiotic codes of historical memory, some of which transform themselves into traveling motives.

$P D$ enters deeply into Paulician doctrine, outlining аногопаєтенит (poly-interlaced, complex, mixed, made by various things) character of their teaching and

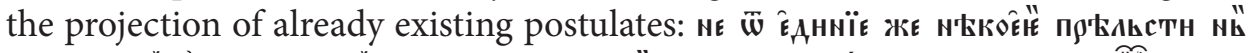

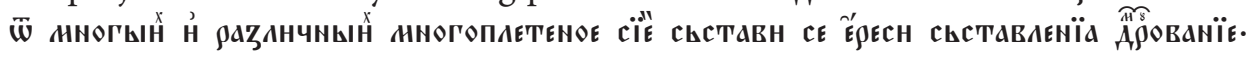
We shall give in schema with key words some emblematic dualistic statements. M. Berke devides $P D$ title against Paulicians into 12 subtitles $^{36}$, the last seven with strongly dogmatic character laying upon excerpts from John Damascene's Expositio fidei, Basil the Great's De Spiritu Sancto, Gregory of Nazianzus' In Sanctum Baptisma, and Gregory of Nyssa's Oratio catechetica magna. In BAR 296, they are fully presented as follows ${ }^{37}$ :

\footnotetext{
${ }^{33}$ К. Станчев, Павликяните..., p. 767. Peter of Sicily tells how Paulicians change their appearance as polypod, or chameleon, speaking one thing by mouth, one another by heart. Р. БАРтикян, Петр Сицилийски..., p. 340.

${ }^{34}$ Ibidem, p. 326 - text edition in Russian translation, p. 21.

${ }^{35}$ Christian Dualist Heresies..., p. 15-16.

${ }^{36}$ M. BERKe, An annotated edition..., p. 47-50.

${ }^{37}$ As it will be proved, this text portion originated from $25^{\text {th }}$ chapter in the Greek $P D$. In Berke's shema both are unified.
} 


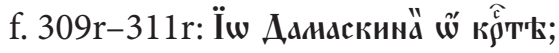

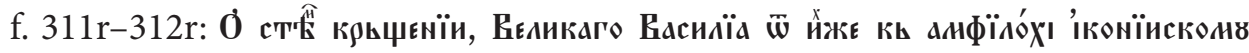
Т९ИАЕЕЕТ'КЙ ГААВИЗнь;

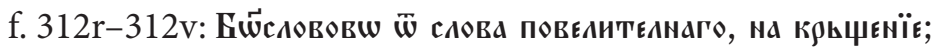

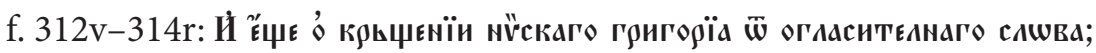

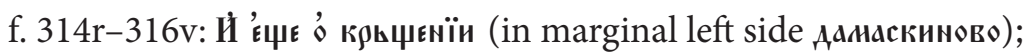

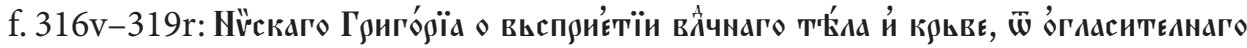
сAWBa;

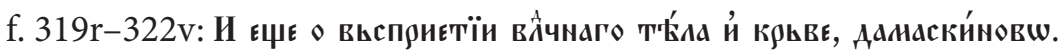

Precedent dualistic views from Paulician doctrine are:

1. Paulicians respect two divine causes as Manichaeans do - celestial father and creator of the world; good and evil (in Slavonic влаго и лоүкаво); hence, the world originated from the devil.

2. Paulicians called themselves Christian but do not believe in Holy Trinity.

3. They defame Theotokos calling her 'Heavenly Jerusalem?.

4. Paulicians reject the communion.

5. Paulicians reject the cross.

6. Paulicians deny the Old Testament.

7. They defame apostle Peter as apostate from Christ.

8. Paulicians corrupt St. Paul's writings.

9. They deny the Holy Church.

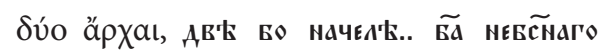

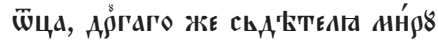

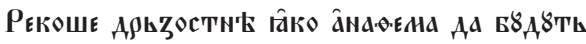

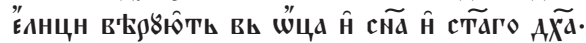

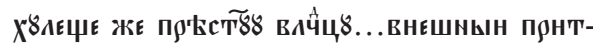

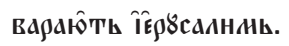

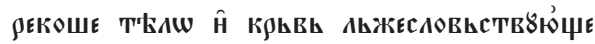

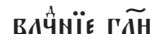

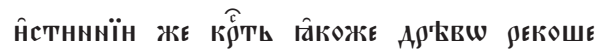

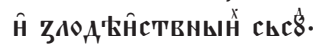

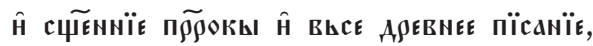

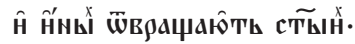

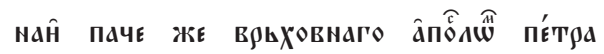
ZАOXУАETL,

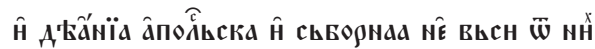
сьставдаюिть А९รгынды

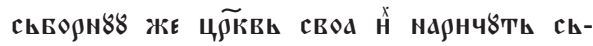
ньмнца. 
10. They reject the baptism.

11. They do not admit the clergy.

12. They live in drunkenness and debauchery.

13. Of special attention is the theological controversy against Paulician idea on the genesis of evil from darkness and fire, and on fire as devil's creation. Zigabenus defends all perceptive world (чювьсттвьно) originated from Demiurges God.

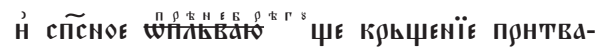

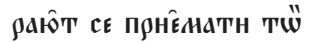

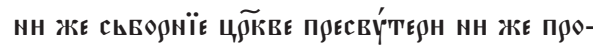

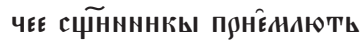

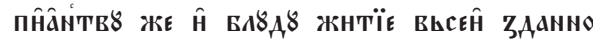
Нิ'н8ть

The conclusion is marked with cinnabar to signalize an especially important passage

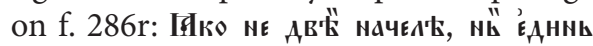

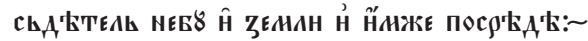

What has been stated insofar reveals the common grounds of the medieval dualistic heresies of Manichaeism, Paulicianism, and Bogomilism which caused their mutual replacement in terms of both dogmatic and nominative prospective. By its geographic origin in Armenia, Christian dualistic teaching of Paulicianism affiliates to Armenian heresy too. Those multi-directional relations transformed it in universal dualistic code. In previous publications, we had the occasion to expose some conclusions based upon Slavonic translated sources of Canon law discipline how the term 'Paulician' became hyperonymic one for representative of heresy, or dualistic heresy in a whole. Data base provided concentrate into so called 'Pseudo-Zonaras penitential nomocanon', the Nomocanon of Slavia Orthodoxa, with rules referring to Paulicians, alongside with Jacobites, Armenians and Bogomils, Patarens, as well as against Paul of Samosata (260-272) and Paulicians

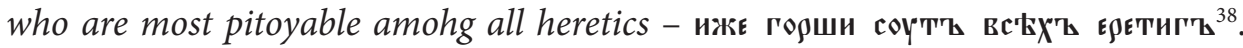
In this way, in this translated Slavonic source the references to Paulicians count three cases, mostly prohibitions against communication, eating and drinking with them. Another example from $14^{\text {th }}$ century Russian Troitski miscellany copied upon a Southern Slavic protograph replaced the more frequent appellative є९єти-

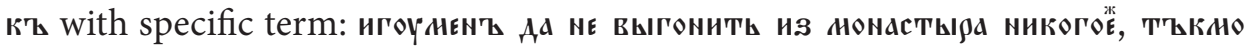
иже БоүАєть Павликеанин'ъ (Abbot should not chase away somebody except he is Paulician $)^{39}$.

\footnotetext{
${ }^{38}$ M. Tsibranska-Kostova, M. Raykova, Les Bogomiles et (devant la Loi). Les sources slaves de droit canonique à propos de l'hérésie aux XIV-XV ss., RESEE 49.1, 2011, p. 15-33; М. ЦиврансКА-КостовА, Покайната книжнина на Българското средновековие IX-XVIII в. (езиково-текстологични и културологични аспекти), София 2011, p. 259-380.

${ }^{39}$ J. Popovski, F. Thompson, W. Veder, The Troickiy sbornik (cod. Moskva, GBL, F.304, TroiceSergieva lavra N 12). Text in transcription, ПК 21/22, 1988, p. 52.
} 


\section{Some notes on the Slavonic translation of $P D$ accordingly chapter $21^{\text {st }}$}

1. The chapter against Paulicians with original numbering 24, in some Greek manuscripts merges with the subsequent one intitled On the Saint Cross, Saint Baptism, and the Secret of Eucharist. This is a pure dogmatic exposition whose Slavonic translation was frequently used in Orthodox theological controversies in the $17^{\text {th }}$ century. Nevertheless, the opposite Greek textual tradition, attested by majority of sources, comprises the independent existence of $25^{\text {th }}$ title separately from the precedent ${ }^{40}$. BAR 296 must have been copied upon a Greek apograph belonging to the first line of text spreading. The Slavonic manuscript attests the union between original Greek titles $24^{\text {th }}$ and $25^{\text {th }}$ without use of any mark to separate visibly them. In this way, as true final of the Paulician account should be considered f. 309r ( $P G$, col. 1243-1244). Consequently, the statement that the title $25^{\text {th }}$ of Greek $P D$ is missing from Bucharest manuscript, should be corrected ${ }^{41}$. It is an integral part of the Slavonic translation, and takes place in the $21^{\text {st }}$ Slavonic title against Paulicians.

2. Nina Gagova formulated an important conclusion on the scribe's attention to both Slavonic translation of $P D$, and its copy BAR 296, as far as she claimed translator and copyist to have been identic person ${ }^{42}$. We consider this hypothesis reliable and supported by the marginal note on $\mathrm{f} .193 \mathrm{v}$, published for the first time also in Gagova's works. The note gives reasons to suppose that the anonymous man of letters not only translated $P D$, but tried to fill up gaps in his prime Greek source by consulting another Greek copy from Vatopedi monastery on Mount Athos. Because the scribe tells the readers he has taken the copy from there - и визинь изь Ватшппда тыёже книгы, it is hardly plausible to presume another explanation except copying to have been located on Mount Athos too. In that optics, the act gives evidence to the mutual relations between monastic Athonite communities. The given testimony coincides with commonly expressed scholarly evaluation that the scribe's handwriting reminds a hesychast scripture, namely Greek-made semi-cursive, typical for monks hesychasts in Tărnovo and on Holly Mountain. Other self-written marginal notes reveal specific moments of copyist's work: he corrected himself for not putting cinnabar on the wright place; made comments on Greek words. Gagova's opinion of translator's working copy, illustrating the process of translation, remains the most plausible insofar. Slavonic chapter $21^{\text {st }}$ is

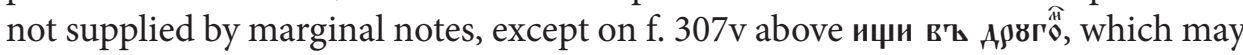
refer to the second Greek source, so that the given information from $21^{\text {st }}$ chapter

\footnotetext{
${ }^{40}$ N. Miladinova, Panoplia Dogmatike..., p. 102.

${ }^{41}$ К. Иванова, О славянском переводе..., р. 102.

${ }^{42}$ Once again, the author exposed all noted by her peculiarities in: Н. ГАговА, Владетели и книги..., p. 136-137.
} 
coincides with scribe complaints on $\mathrm{f} .148 \mathrm{r}$ for lacunas in the first Greek apograph. However, inside the main text, one can observes some corrections or hesitations over the choice of words and constructions, as found in other parts of the manuscript. We shall draw attention only to one significant passage from $P D$ accordingly Photius's beginning of the original $24^{\text {th }}$ title, which tries to explain the difference between Paulician absolute dualism and Orthodox Christians' faith, called ринағанє (in Greek Romaions). The scribe's self-correction element is as follows:

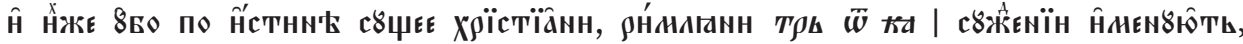

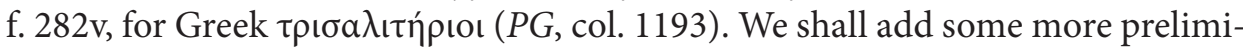
nary opinions and ideas:

- the scribe-translator uses individual marks of stylized effect inside text or in the last line when writing comes out of it; applies modest decoration of small cinnabar initials for text segmentation; carries out an attentive philological work, reconciling constantly the Greek original. Most probably he wrote long time, changed the ink and the letters size (f. 221v-222r; 223v-224r) in order to conform with his paper material. The supplementary watermark 'enclume' in $21^{\text {st }}$ title from BAR 296, alongside with 'dragon', gives perhaps favor to this supposition. These are two of the sixth watermarks in total, which allow the dating of BAR 296 between 1410-1420r ${ }^{43}$;

- the predominant amount of marginal notes represents portions of the basic $P D$ text, but there are also some comments and explanations. Among the philological ones, some of the more interesting are the substitution of the gr. adek-

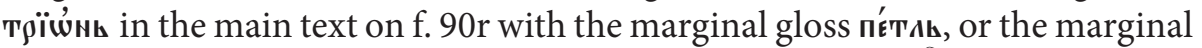

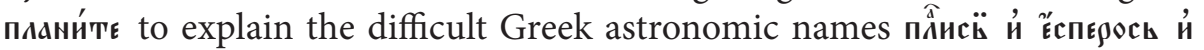

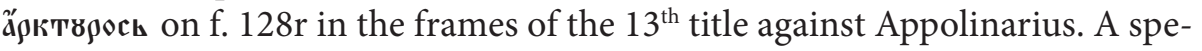
cial attention deserves the fact that on ff. $237 \mathrm{v}-238 \mathrm{r}$ the scribe scratches the beginning of the $18^{\text {th }}$ title, which was not placed appropriately before the $16^{\text {th }}$, but further copies it on the correct place on $\mathrm{f}$. $245 \mathrm{r}$ in revised version in regard to the wrong beginning. Thus, in BAR 296, one faces "a critical spot" of the textual history which illustrates once again the process of translation. The most plausible reason for is the uses of two Greek sources;

- it seems to us that the scribe's explanation about the translation of Greek prepositions and conjunctions with Slavonic synonyms, witnesses to the special attention towards the correctness of the verbal sign. This is a typical element of the hesychast logos paradigm. Besides the already described by Gagova case

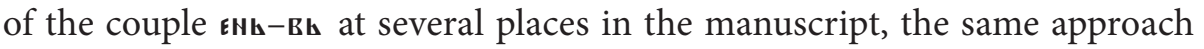
refers to the conjunction кal-n in the extended explanatory note on f. 61r;

\footnotetext{
${ }^{43}$ Л. ВАСИљЕВ, М. ГРОЗДАНОВИЋ-ПАЈИЋ, Б. ЈовАНОВИЋ-СТИПчЕВИЋ, Ново датиратье српских $p$ кописа у Библиотеции румунске академије наука, АПри 2, 1980, р. 56, № 60.
} 
- with regard to deacon Yacob, who left a note on the flyleaf recto (f. 1r) of having bound the book body and copied the first two tetrads, he succeeded quite a lot in confusing scholars by mentioning Photius's epistle to the Bulgarian prince Boris-Michael, which is actually missing from the manuscript content. In fact, Yacob copied the very beginning of the numbered as $12^{\text {th }}$ title, the first one in BAR 296. We should not forget the ending of the Greek PD in some manuscript branches namely with the same epistle. Therefore, the mention of Photius's epistle could be possibly not a mistake or hazardous, but an analogy, bearing in mind that BAR 296 does not contain the original Greek $13^{\text {th }}$ title with another Photius's famous work from 867 about filioque controversy, and that the mention is preceded by some Photius's paratitlo, i.e., by a concrete still unidentified textual segment. It might have a deeper explanation of the given fact. As a whole, BAR 296 needs a new comprehensive description of its content in conformity with the numbering and the dogmatic issues of all titles/chapters treated in the original Greek Panoplia. In the frame of this study, we shall conclude that BAR 296 consists of 11 titles, but they do not entirely correspond to the arrangement and the content of the second book of the Greek $P D$.

3. The eminent scholar Klimentina Ivanova drew the preliminary conclusion of syntactic and lexical proximity between $P D$ Slavonic translation from one side, Bulgarian patriarch Euthymius of Tărnovo's works and the production of Tărnovo Literary School, from another ${ }^{44}$. This opinion is also worthy of scholarly attention, as so complex dogmatic writing with difficult terminological meaning could not be at virtue of accidental or uneducated translator. In the beginning of the $15^{\text {th }}$ century, patriarch Euthymius's legacy found continuers in the community of disciples and collaborators, who migrated to Athos, Moldova, Serbia, Wallachian principalities. Several linguistic traits could be easily noticed although summarized merely upon the analysis of one title:

- to begin with, a high percentage of composita, some of which do not belong to the most spread models and types: таиноводиствовати, таиноводствовавь-

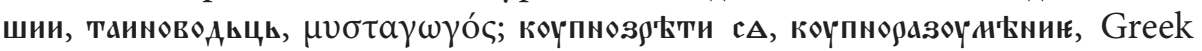

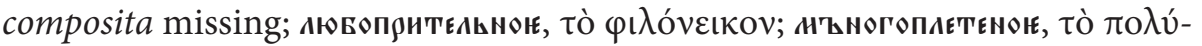

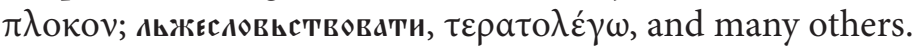

- outlined high percentage of poly-prefixed verbs with more than one prefix in purpose of seeking for semantic nuances: вьспропов'ддати, пооскврьнгвати,

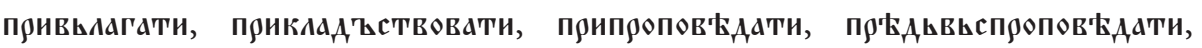

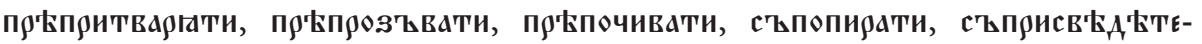
льствовати and so on.

${ }^{44}$ К. Иванова, О ставянском переводе..., р. 105. 
- interesting lexics and uses, as for instance the way Paulicians called Orthodox priests and presbyters съьтъцходьници and нотария; everywhere овласть instead of власть; д ВАатєльница in the meaning of 'place of action' for Greek

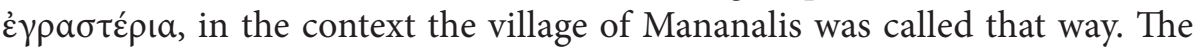
frequent comparatives and superlatives are another translating feature варварствн'ЕШЕ, АютТИШЕ, ПО АноГОУ.

The current observations have only preliminary character but allow us to shape the anonymous scribe as personality with deep notions in Greek and very punctual to his Greek sources.

\section{Conclusion}

The two analyzed texts reveal various and purposely-intended data base over the Paulicians and Paulicianism, but also some partly intertextual coherence in the basic mechanisms on how the image of the heretics has been shaped. This image, as stated not once in terms of all heresies, came from adversaries and opponents, but this is namely the medieval heresiology in its both highest models and lowlevel apocryphal branches of literature to remain the most valuable, sometimes unique witness of one heresy background, lifetime and destiny. Analyzing stereotypes of religious and confessional alterity is an adequate perspective methodic and could be applied to various heretic deviations from the sein of Christianity, which were also described and recorded in translated or original medieval texts of different genres (Bogomils, Latins, and so on). This is one of the possible interpretative strategies and approaches, preceded by reliable sourcing and comprehensive historical and philological account, in regard of the Slavonic translation of Zigabenus's Panoplia Dogmatica we do believe forthcoming.

\section{Appendix 1}

English translation of $S$ upon the Slavonic copy and its Polish translation in: Sredniowieczne herezje dualistyczne na Bałkanach. Źródła słowiańskie, ed. G. Minczew, M. SKowroneK, J.M. Wolski, Łódź 2015 [= Series Ceranea, 1], p. 228-231. The translation is made by Marek Majer, to whom I own a great debt of gratitude.

\section{Sermon on the origin of the Paulicians. John Chrysostom's sermon on how the Paulicians came to be}

Bless us, father!

The devil fashioned himself as a grammarian of great comeliness and wisdom, meek, of a gentle speech. And he came to Saint Basil. And Saint Basil, seeing the remarkably fine writing of his hands - such as he had never seen before - and 
seeing him so humble, rejoiced deeply, for he did not know that it was the devil. And the devil wanted to deceive Basil. Basil took to him greatly and entrusted him to write books. The devil took two disciples from among the people and wrote magnificent books in Saint Basil's home, so that Basil was overjoyed with him and said to the devil: "O grammarian, write a manuscript with your hand, so that I can send it to our patriarch John Chrysostom; let him see what grammarian I have". The devil wrote it, and Saint Basil sent it to John, saying: "Look, my lord, what grammarian I have. And when you see his fair appearance, you will come to love him greatly." Having received the letter, John recognized that it was of the devil, and he replied to Saint Basil with the words: "It is indeed a good grammarian that you have. I shall come to see him myself too, so that I might rejoice in him." Then the devil reveled[, living in Basil's home ${ }^{45}$ ]. John, having arrived with all his servants and all his gifts for the church, entered Basil's home[, and they blessed each other].

Basil said: "O my lord, I shall bring before you my grammarian, so that you may see him”. Chrysostom answered: “Do bring him!”. And John saw the devil, who had made himself appear fair, and he recognized all his deeds.

John entered the temple; having assumed the throne he cried bitterly and said: "O Almighty, our God Jesus Christ, bestow on us heavenly force so that I might crush this devil." Basil said ${ }^{46}$ : "Indeed, nowhere is there another grammarian like this one." John kept on watching the devil, summoned everybody to the temple, brought all the church gifts inside and sealed all of the temple treasures with the name of Christ; [afterwards] Saint John entered to celebrate the holy liturgy. When he said "Gospel"47, the devil became greatly distressed; Basil saw this and became frightened. When they were bringing the Holy Gifts ${ }^{48}$, the devil turned scary and hit the ceiling of the church, after which he fell to the ground again; all the people became confused and panicked. Saint John was bolstering their spirits. And when

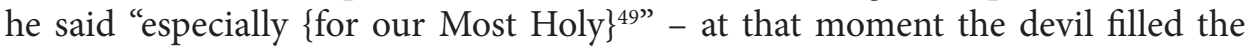
whole temple; and when he said "the only light"50 - then the devil exploded.

Having exited the church, John said: "O Basil, do you not see what kind of grammarian you have? Do you not know, father, that everything in the world that is exceptional and unseemly to the people comes from the devil?" Having collected all of the books written by the devil, they burned them in fire. Basil said to John: "O my lord, what shall become of these two who are his disciples?" John answered: "They are Christian sons, let us protect them until we see what happens, whether

\footnotetext{
${ }^{45}$ The most important supplements based on other manuscripts are provided in square brackets.

${ }^{46}$ In some manuscripts: "John said".

${ }^{47}$ Part of the liturgy of the Word; a call made before reading the Gospel pericope.

${ }^{48}$ The so-called Great Entrance during the liturgy - the bringing of the Holy Gifts from the Table of Oblation to the altar.

${ }^{49}$ Part of the prayer during the Anaphora, dedicated to the Theotokos.

${ }^{50}$ Another prayer during the Anaphora.
} 
they follow the Christian path." One of them was called Samobatius, and the other Shutiya; the devil's name was Upael.

The two disciples of the devil rose and came from Cappadocia to the Bulgarian land, and having adopted the apostolic name of Paul, they taught the Bulgarians to worship Paul. And thus the people who accepted this law call themselves Paulicians.

Looking for them, John left Constantinople and came to Petrich, where the Theotokos appeared to him in bright light[, as queen]. He sent envoys and they brought these Paulicians from the Bulgarian land, and on his orders, they were flayed alive, since their skin was baptized and the Paulicians considered themselves to be suffering excruciating torments for Christ ${ }^{51}$. And then they were calling themselves Paulicians, because [they accepted] the enemy's teaching. Saint Basil ${ }^{52}$ said: "Accursed be the evil teacher's disciple".

To our God be the glory forever and ever, amen, amen, amen.

Appendix translated by Marek Majer

\section{Appendix 2}

Text sample from the $21^{\text {st }}$ title against Paulicianism accordingly BAR 296, f. 280r-292r, and the true final of the title with the last paragraph concerning directly Paulicians on f. 308v-309r, just before the merge with the original $25^{\text {th }}$ title of the Greek $P D$. The extended Slavonic text does not allow to be published entirely, neither objectives of the current subject require. We follow the practice of several partial editions and translations, quoted in the study, dealing also with text samples and purposefully chosen text illustrations. A partial new Bulgarian translation of the $P D$ title against Paulicians could be found in Д. РАДЕвА, Павликяни и павликянство в българските земи. Архетип и повторения VII-XVII в., София 2015, p. 521-534.

Editorial marks are: | for line ending; || for page ending. The original orthography and segmentation remain unchanged; original text in vermilion rendered here in bold type.

ff. $280 \mathrm{r}-292 \mathrm{r}$

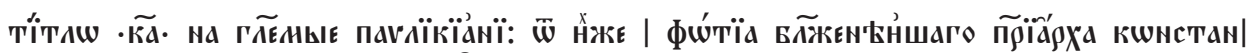

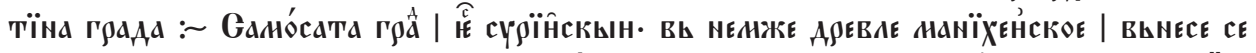

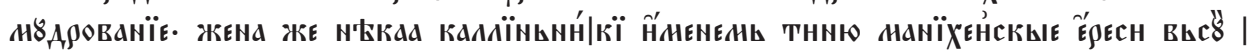

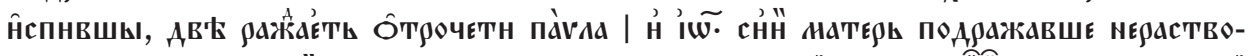

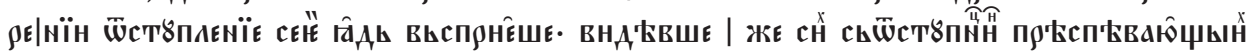

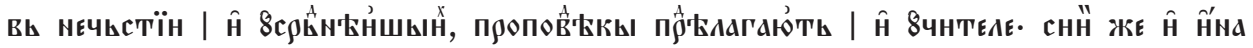

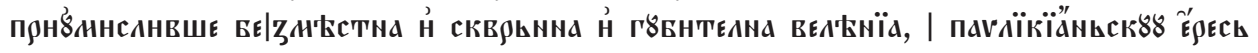

${ }^{51}$ In some manuscripts: "although their skin was baptized, and the Paulicians considered themselves holy". According to the tradition, a similar fate was shared by the founder of the Manichaean religion.

${ }^{52}$ In some manuscripts: "John". 


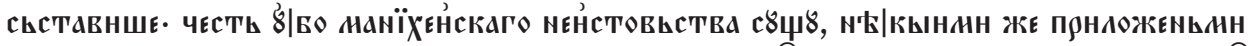

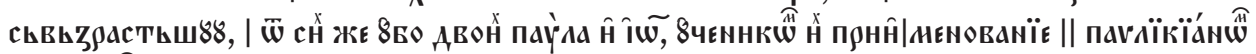

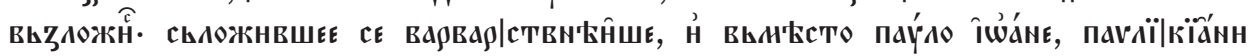

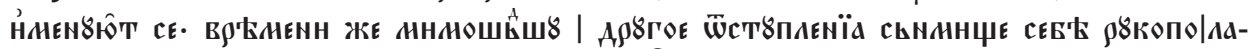

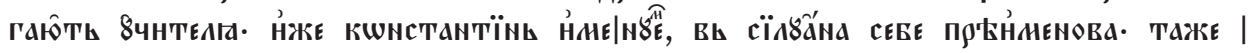

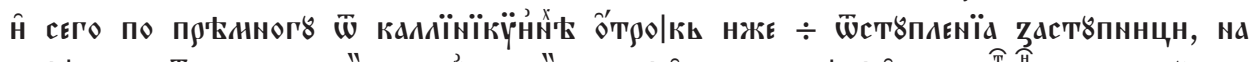

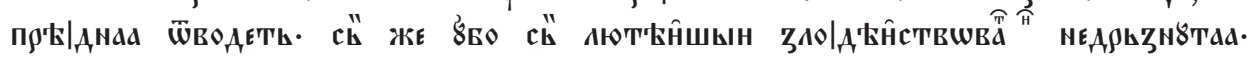
É

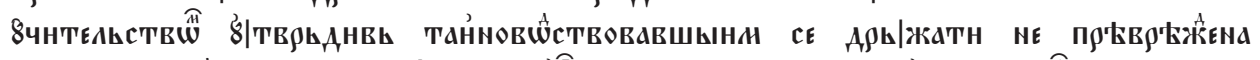

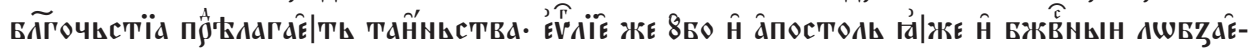

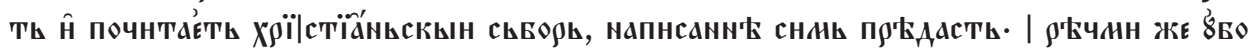

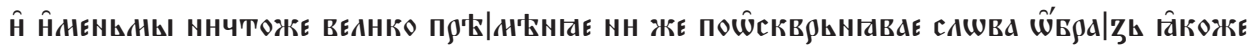

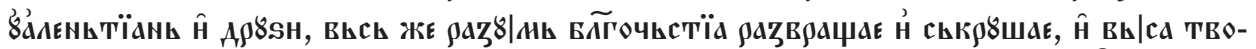

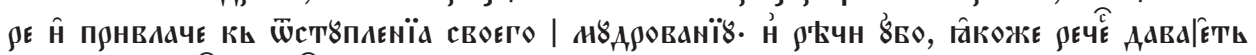
А९ЬЖаты БжВૃ

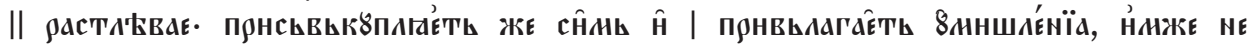

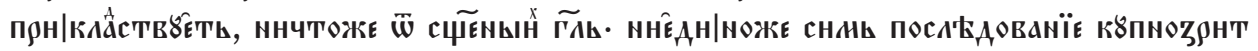

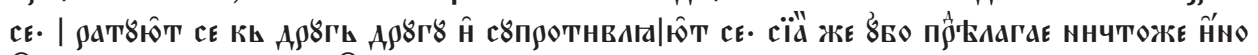

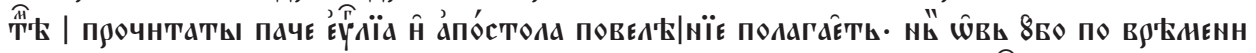

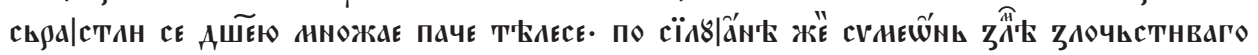

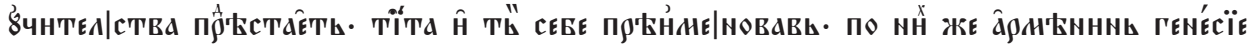

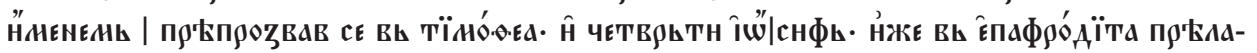

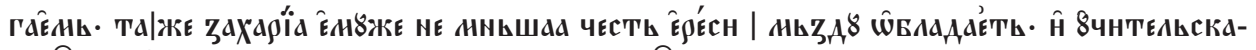

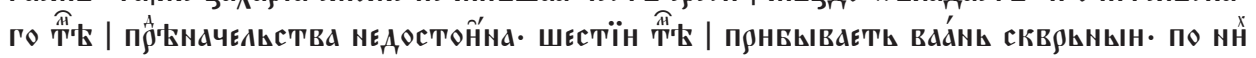

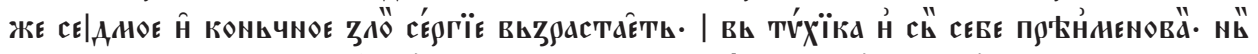

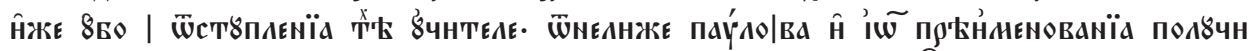

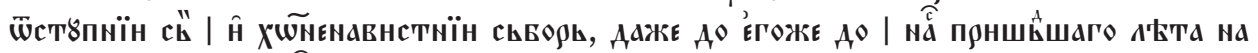

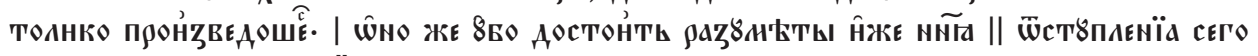

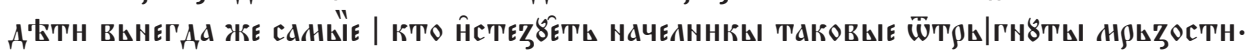

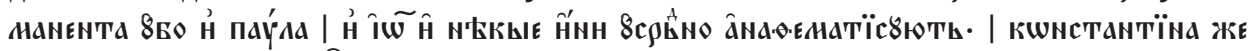

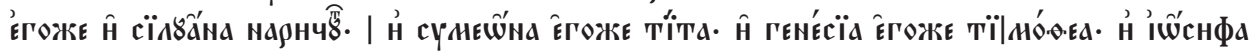

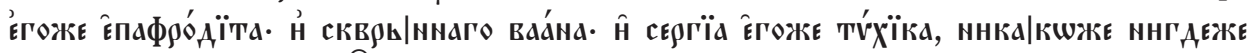

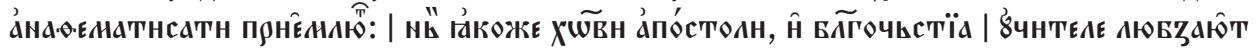

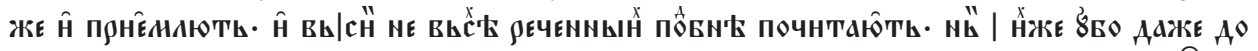

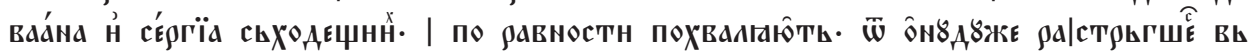

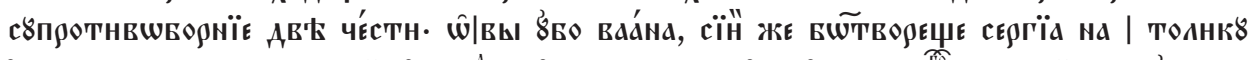

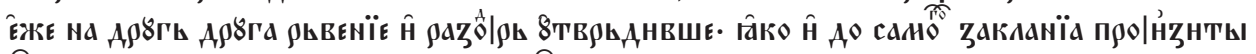

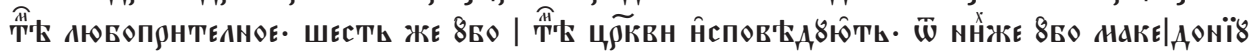

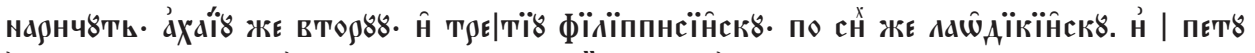

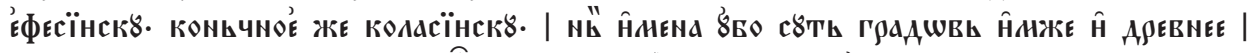

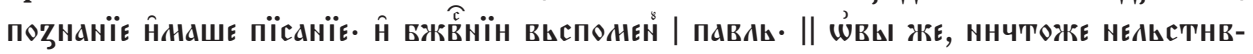




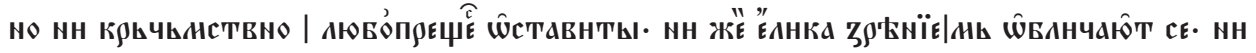

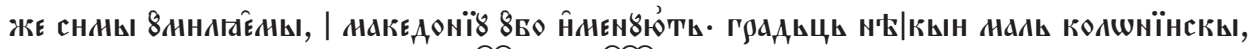

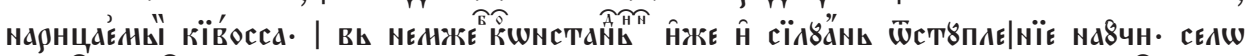

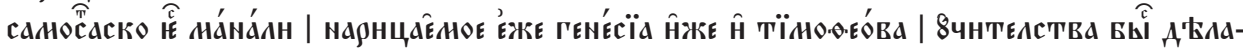

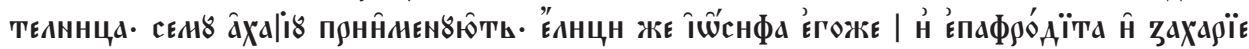

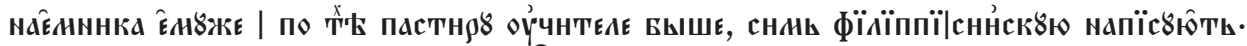

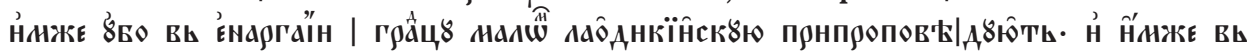

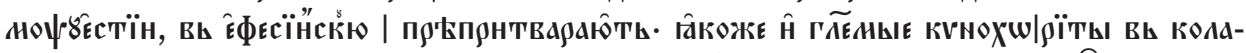

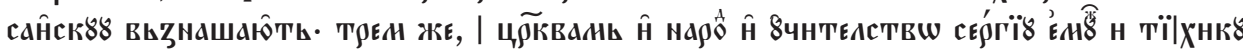

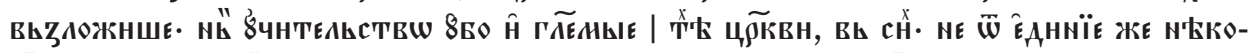

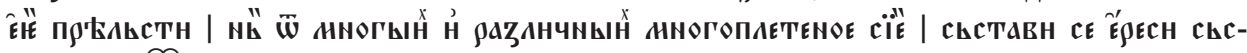

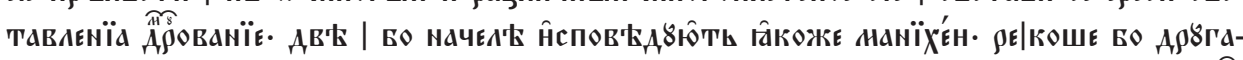

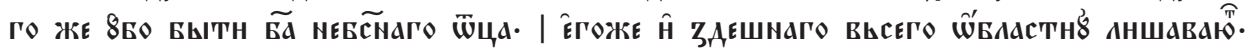

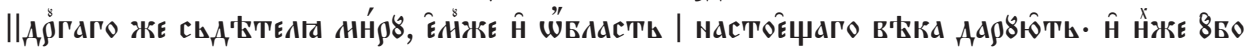

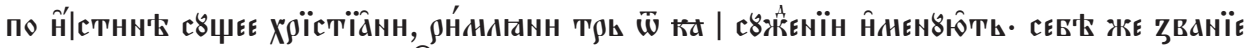

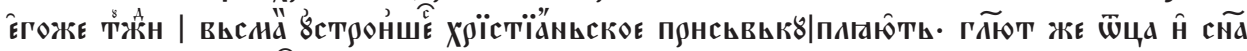

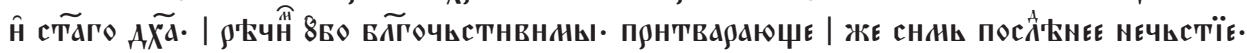

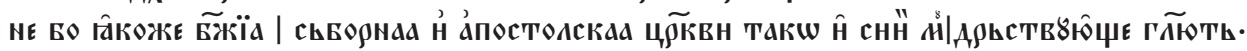

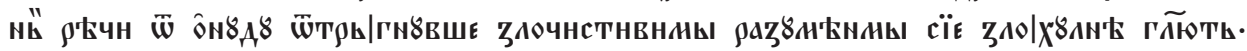

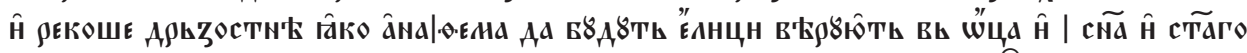

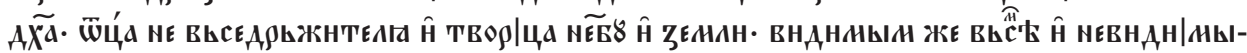

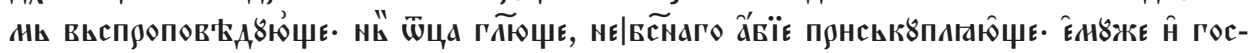

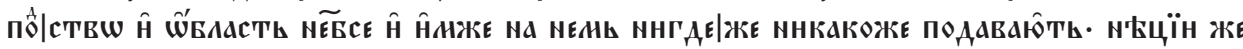

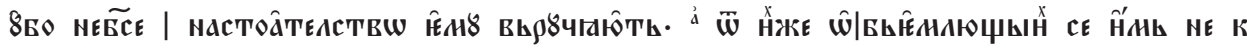

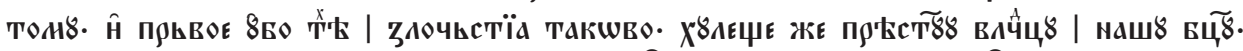

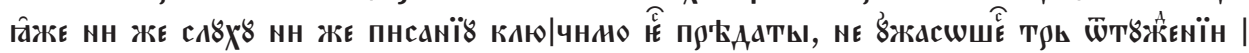

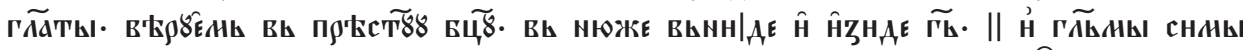

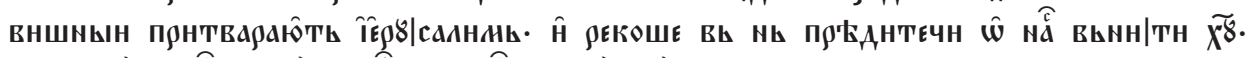

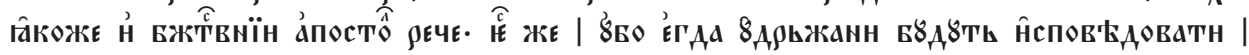

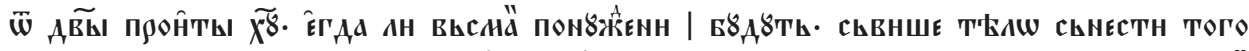

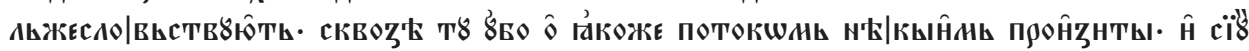

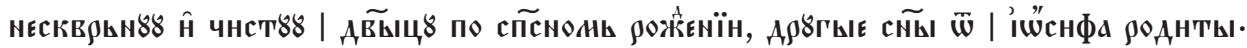

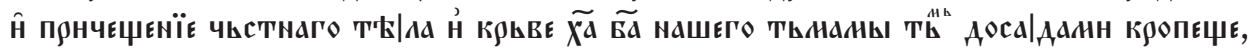

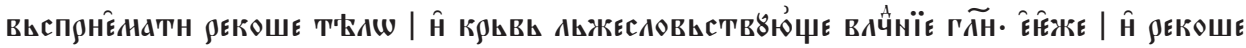

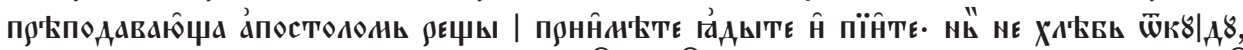

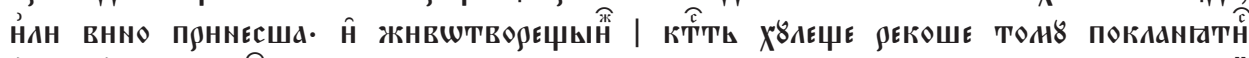

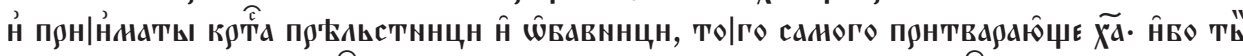

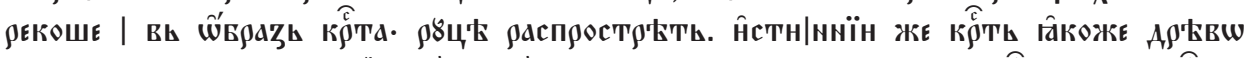

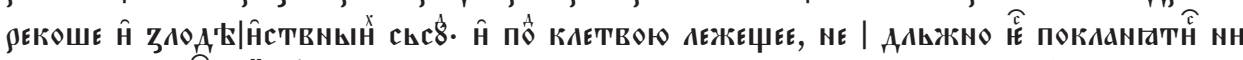

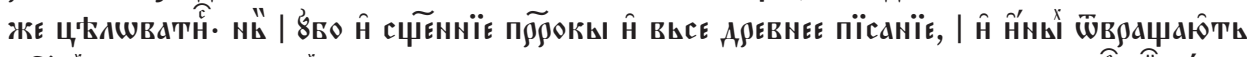
стТ人Н. 


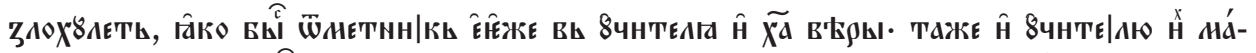

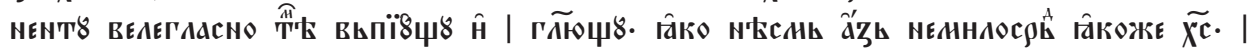

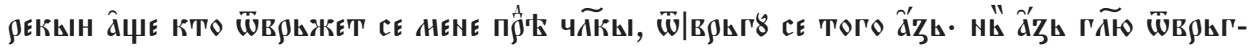

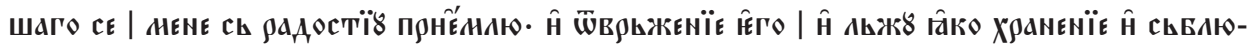

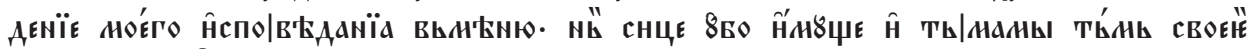

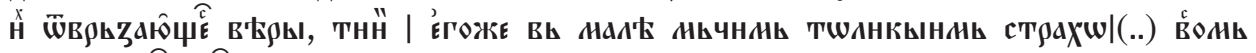

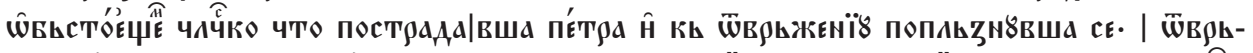

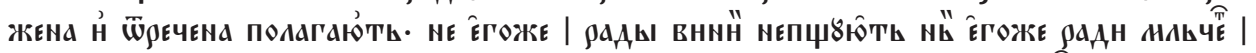

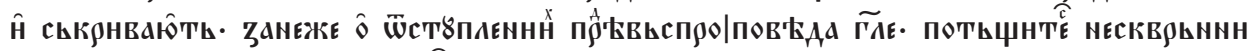

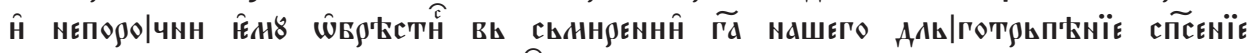

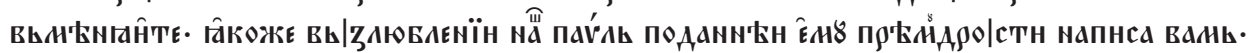

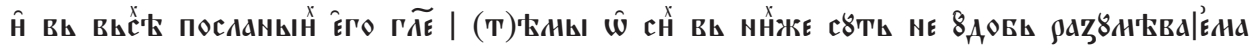

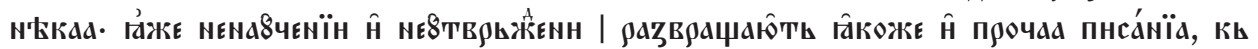

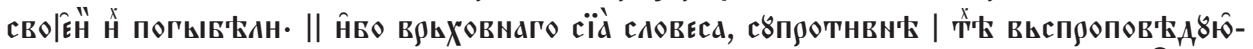

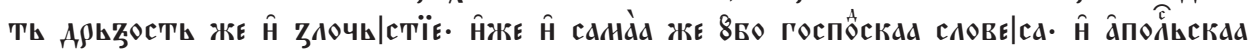

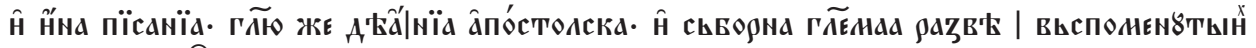

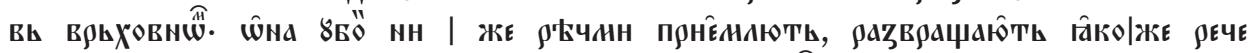

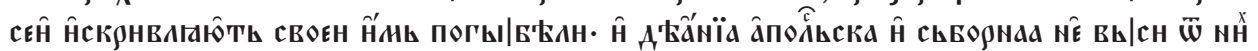

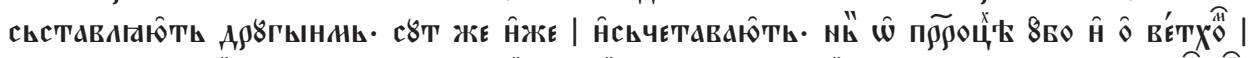

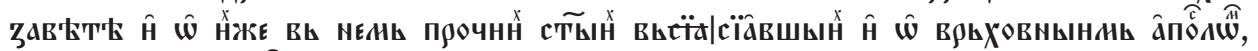

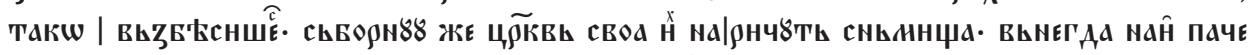

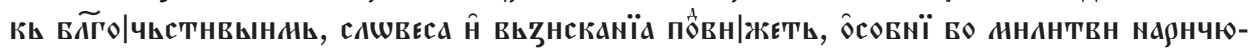

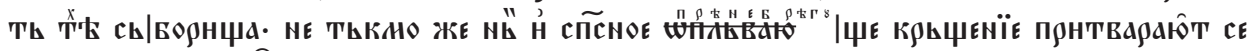

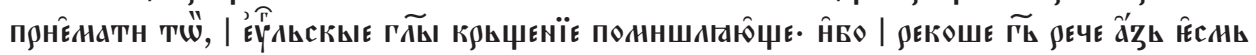

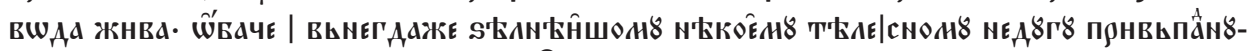

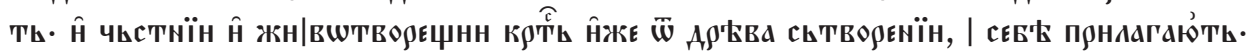

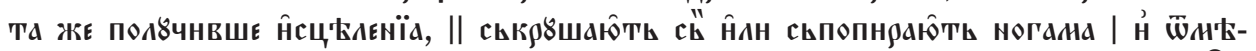

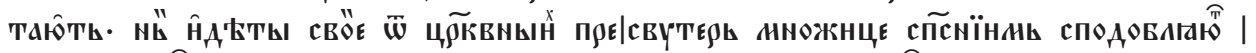

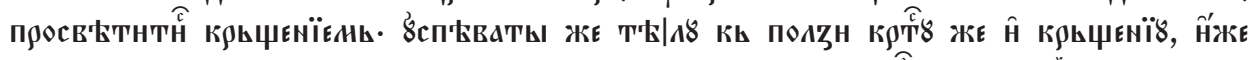

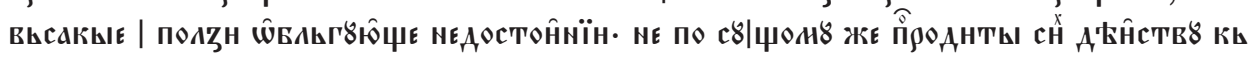

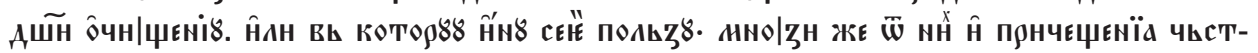

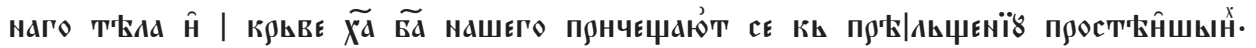

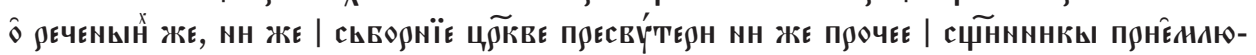

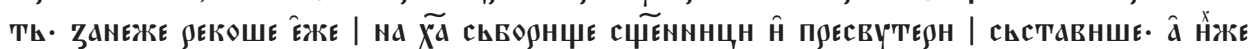

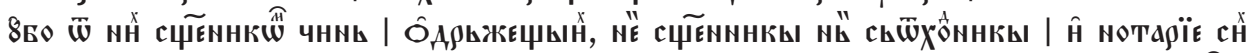

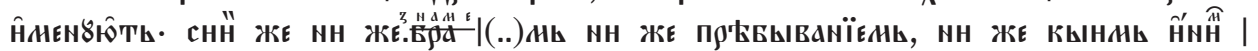

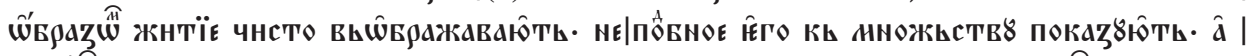

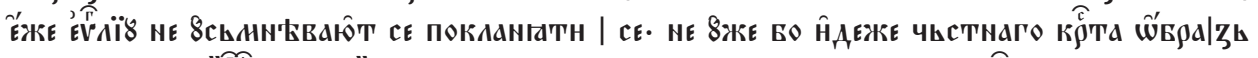

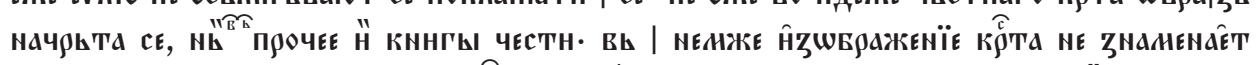

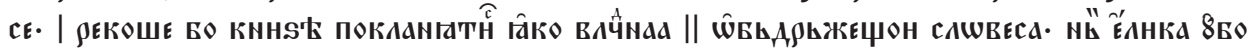

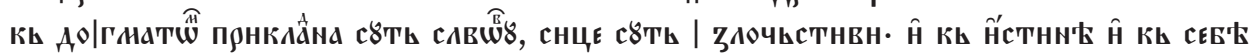




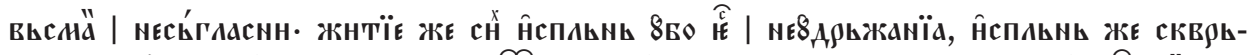

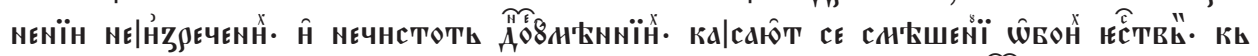

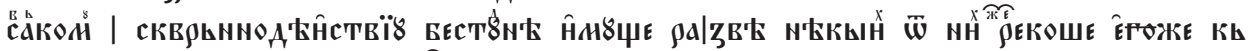

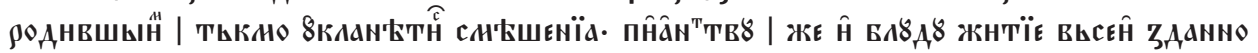

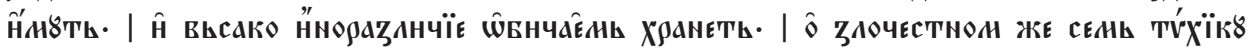
П९нН̂A

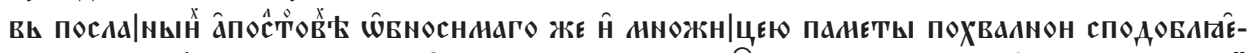

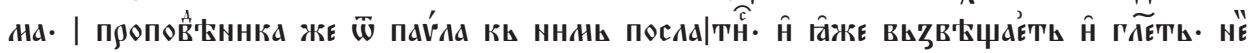

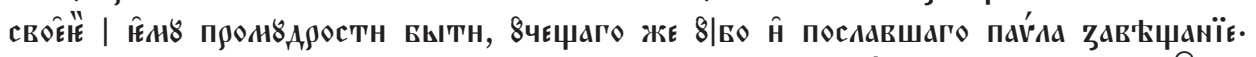

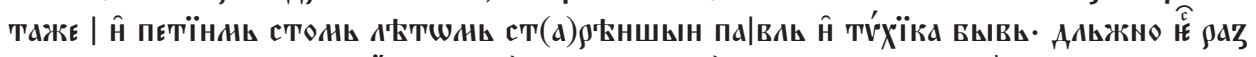

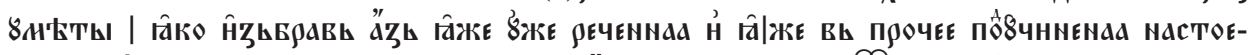

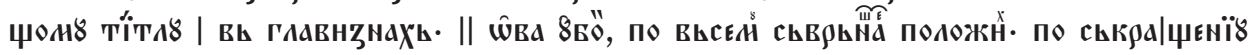

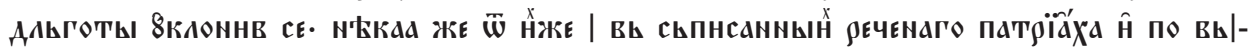

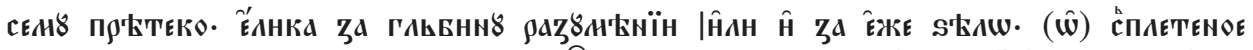

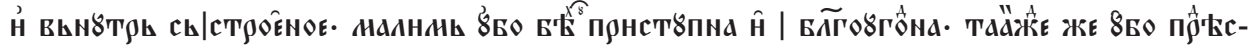

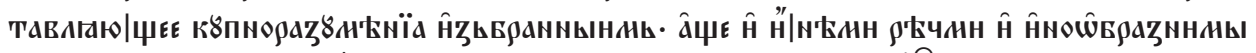

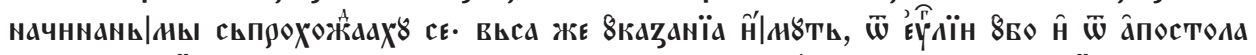

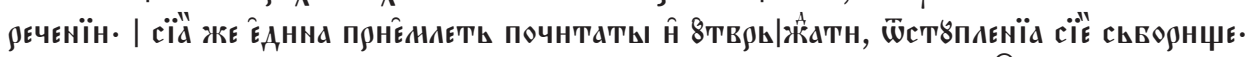

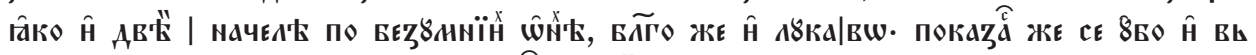

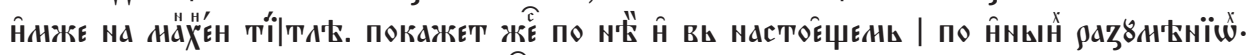

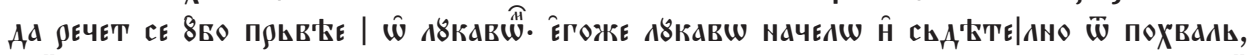

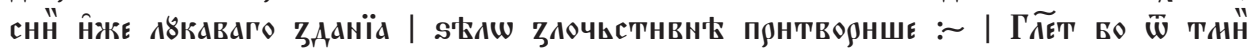

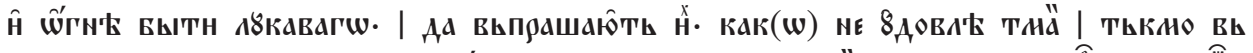

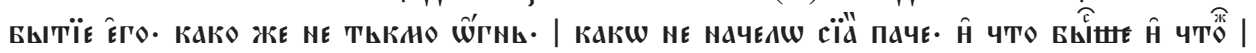

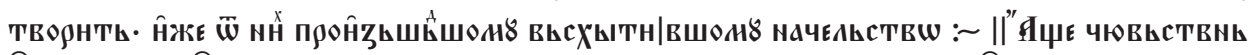

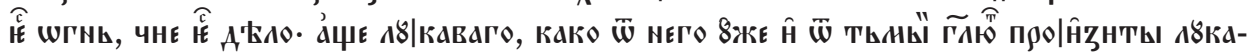

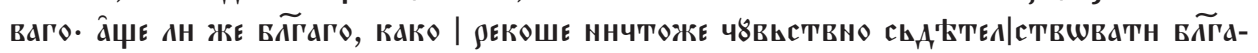

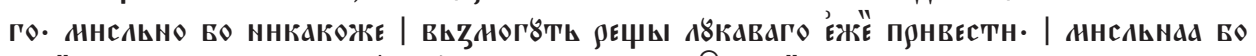

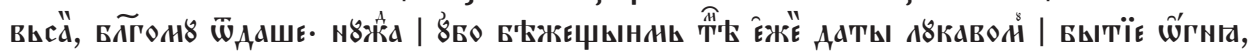
శિКo А⿱

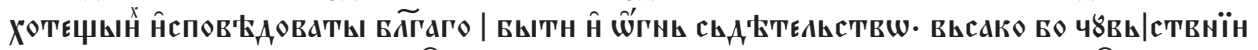

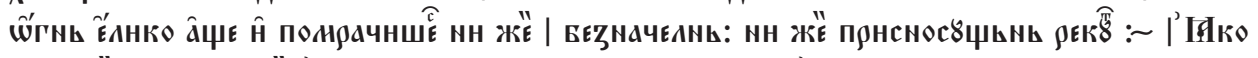

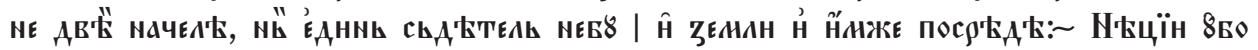

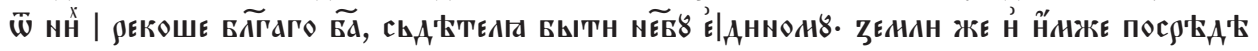

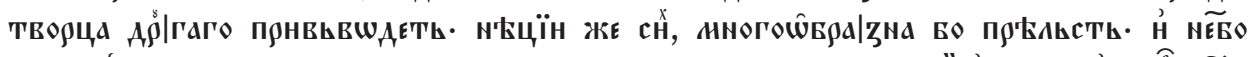
са木но н

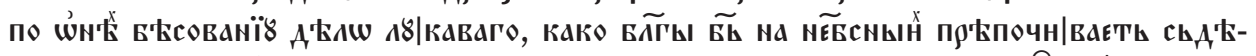

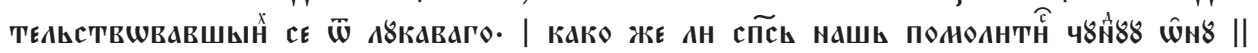

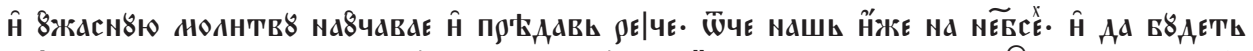

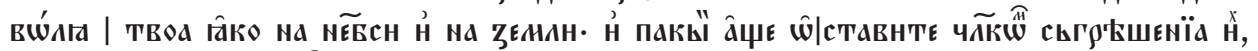

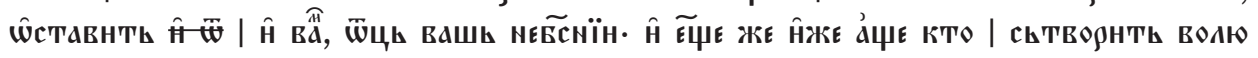




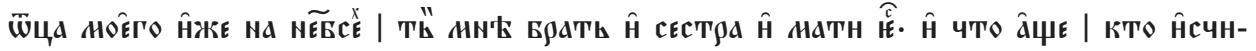

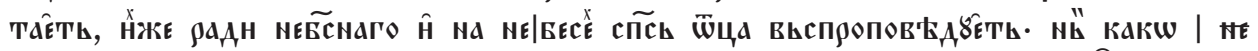

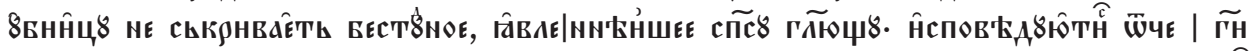

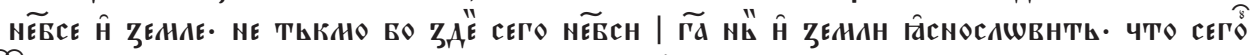
厄ૅ

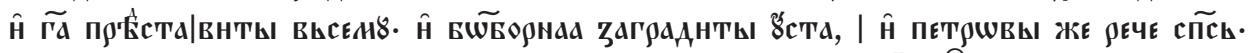

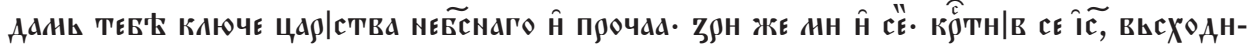

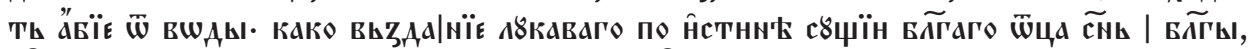

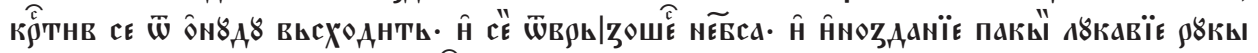

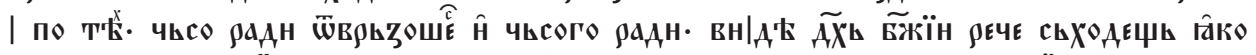

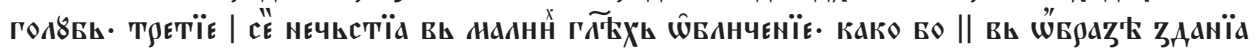

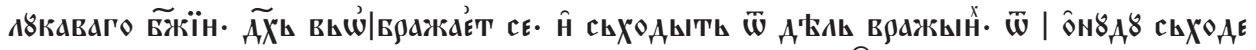

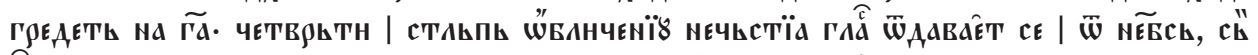

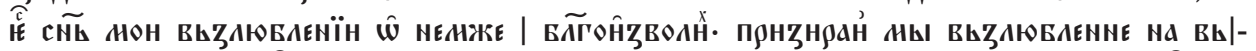

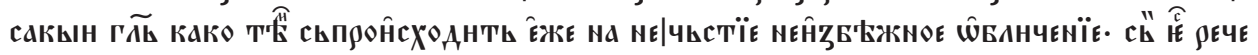

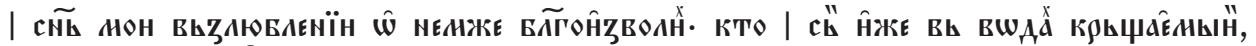

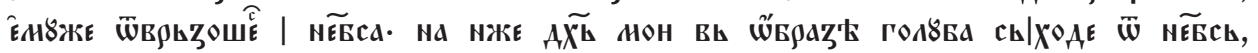

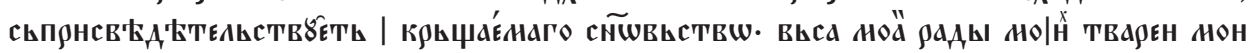

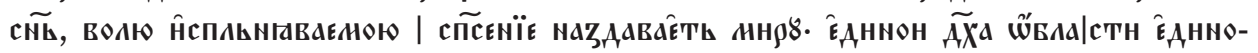

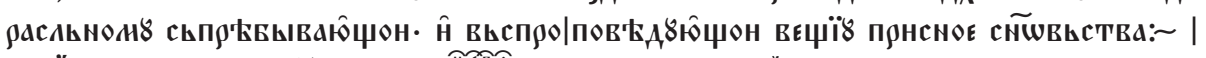

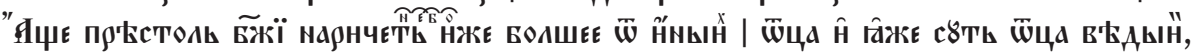

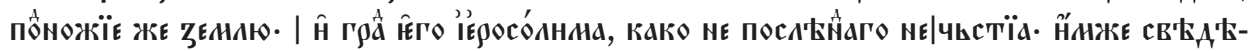

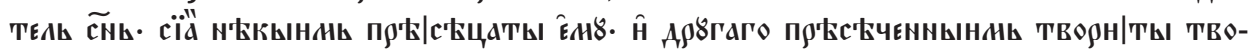

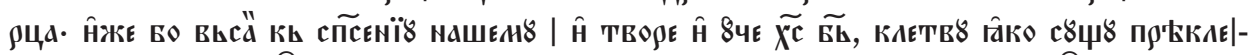

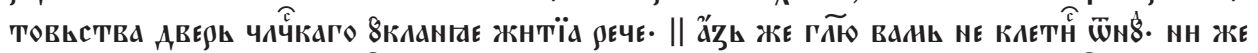

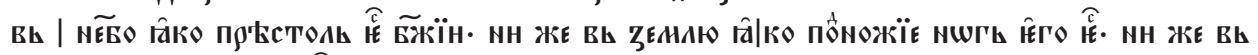

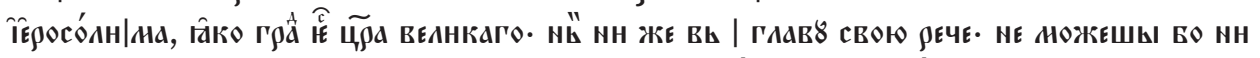

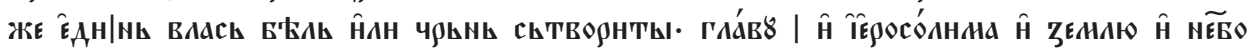

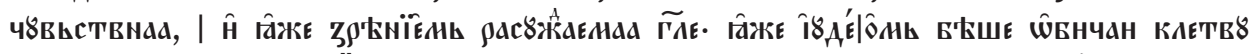

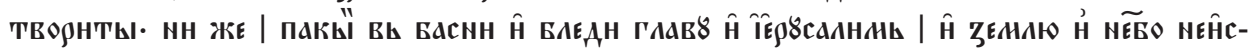

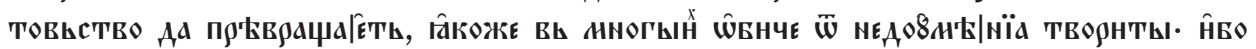

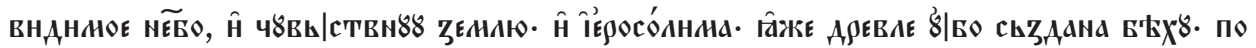

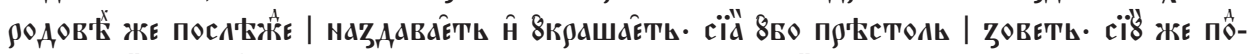

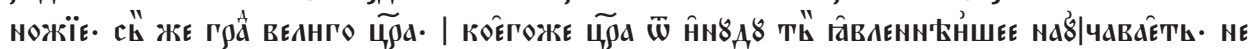

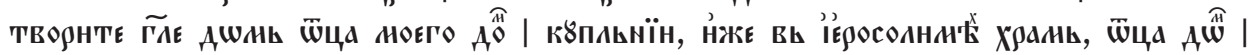

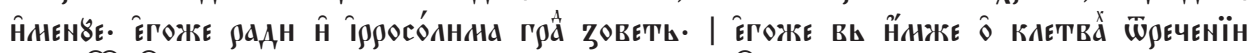

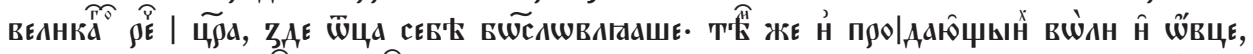

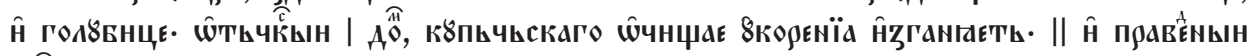

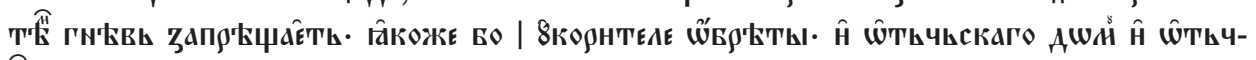
Кं

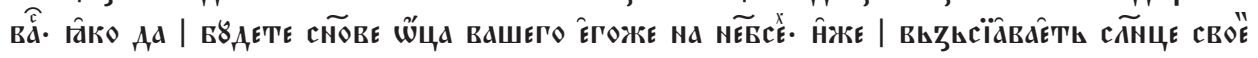




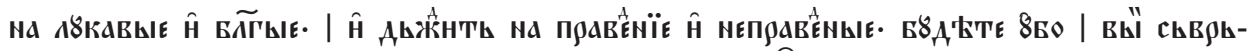

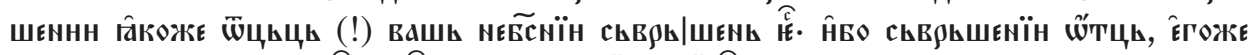

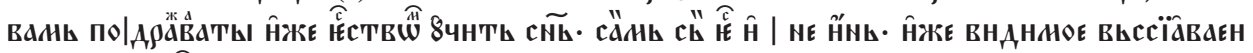

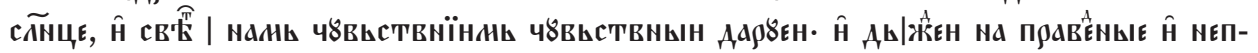

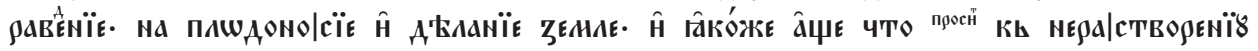

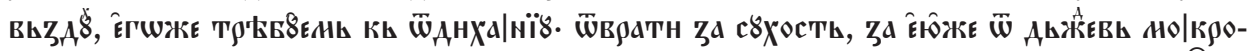

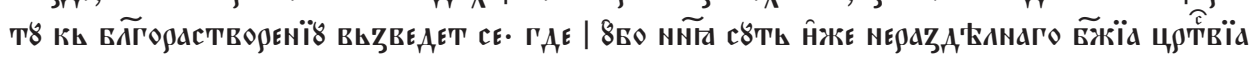

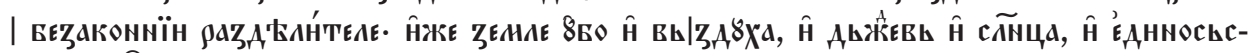

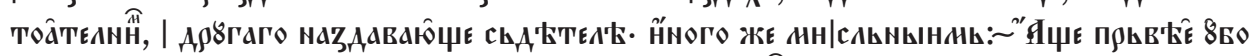

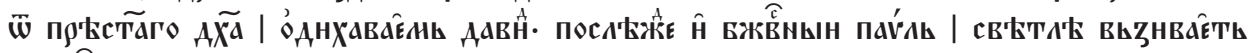

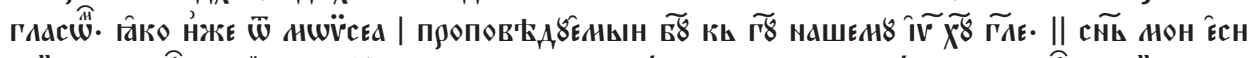

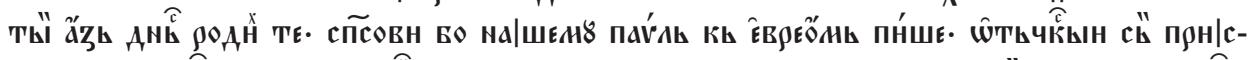

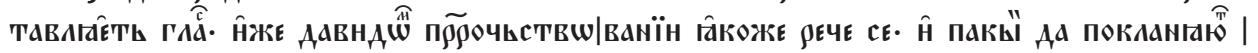

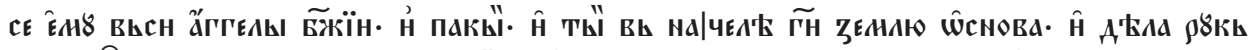

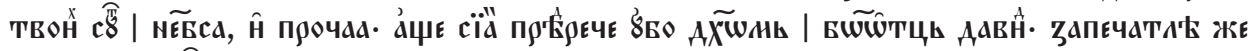

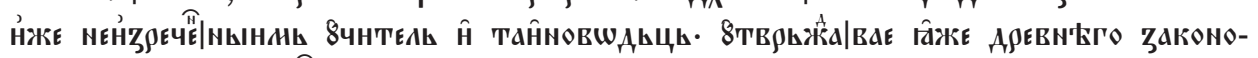

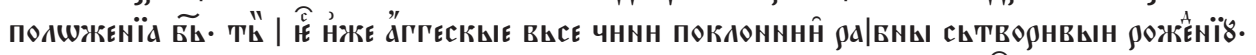

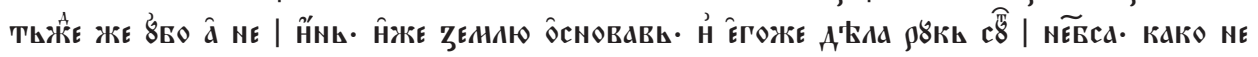

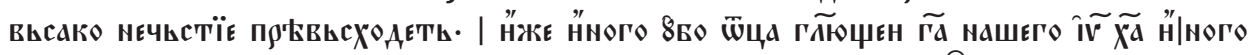

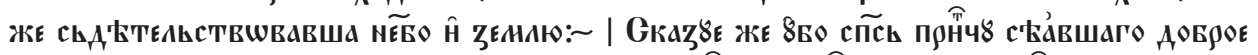

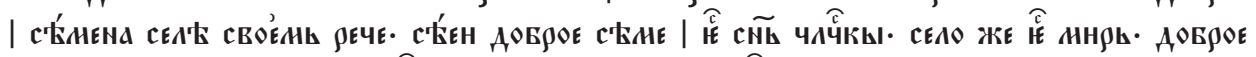

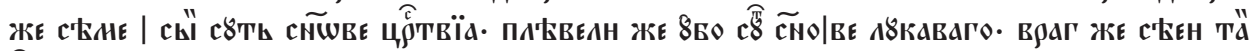

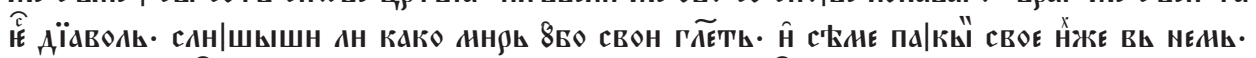

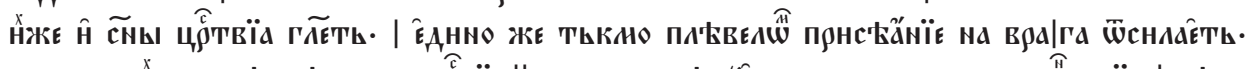

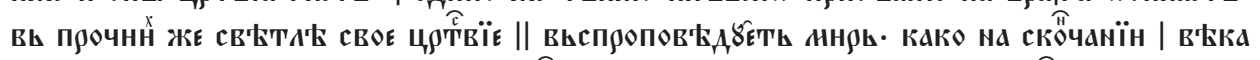

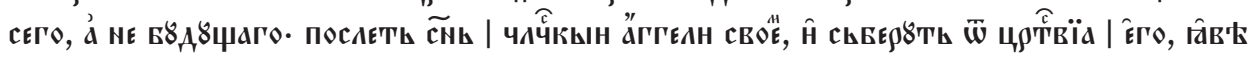

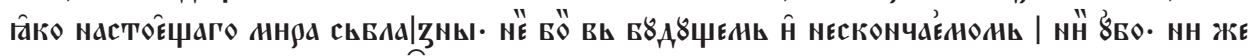

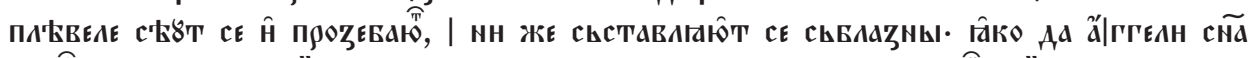
ЧАЧК์

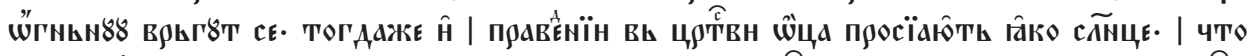

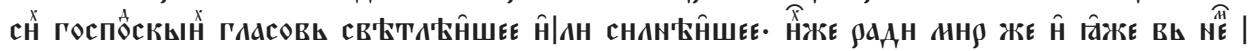

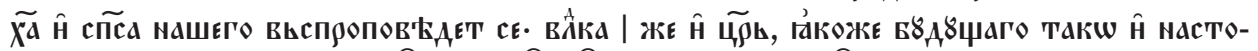

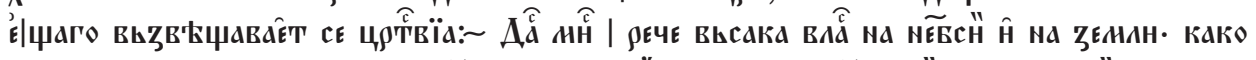

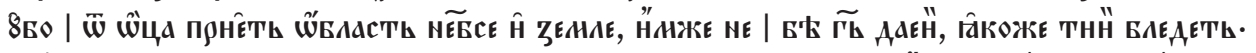

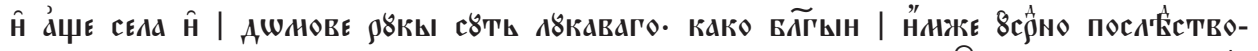

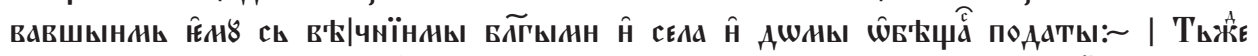

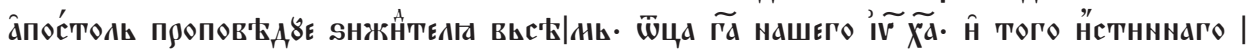

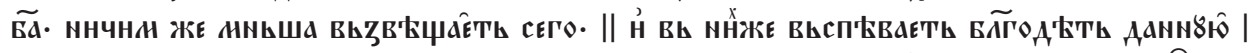

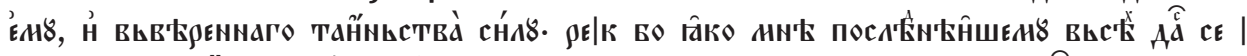

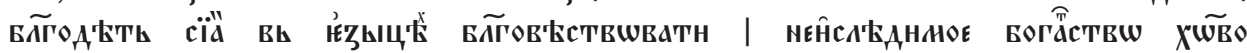

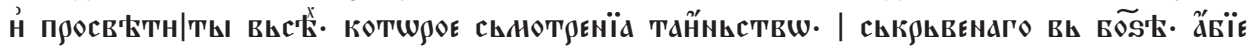




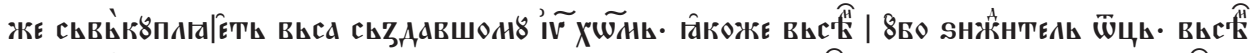

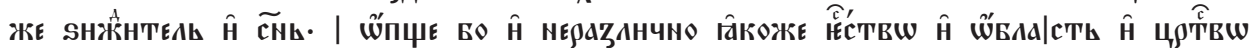

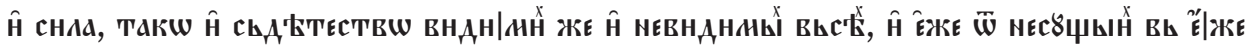

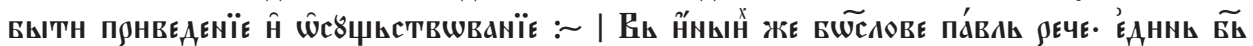

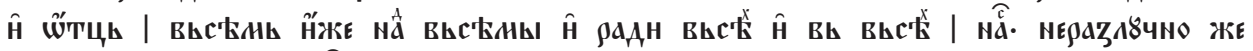

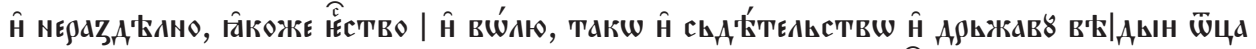

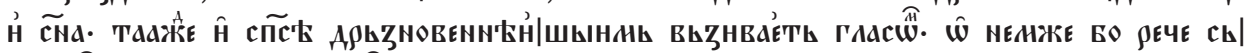

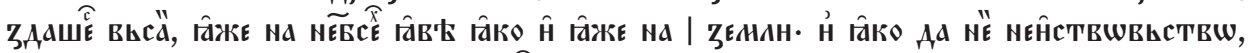

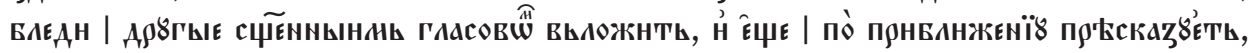

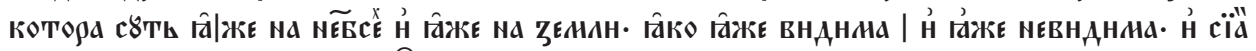

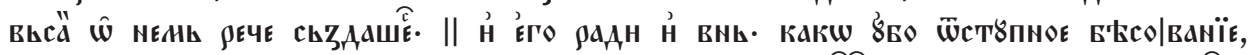

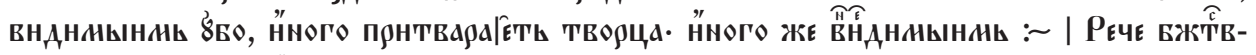

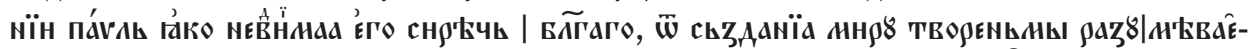

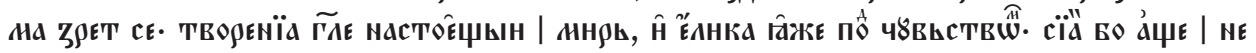

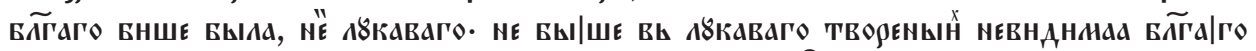

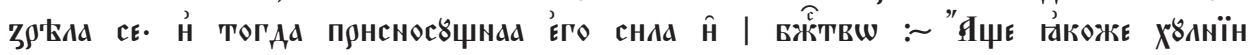

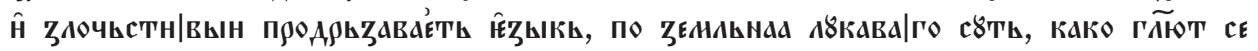

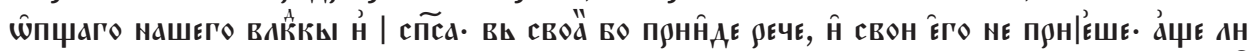

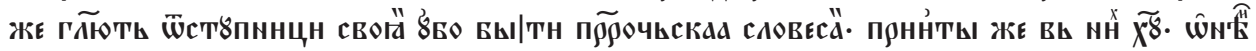

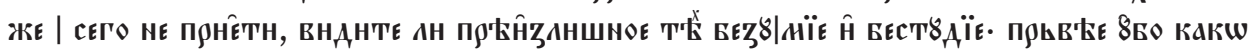

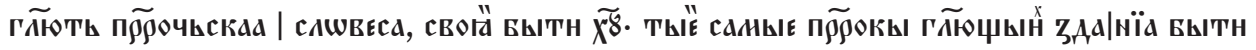

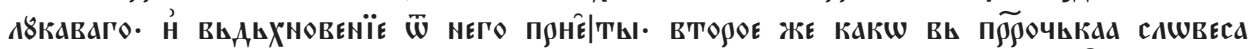

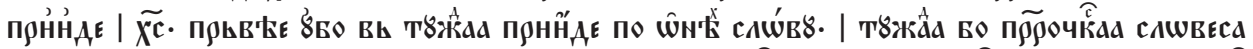

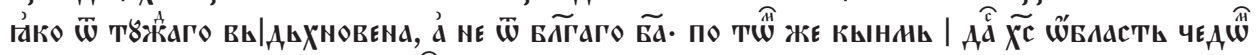

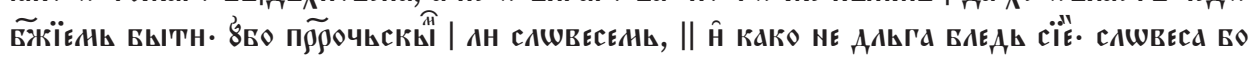

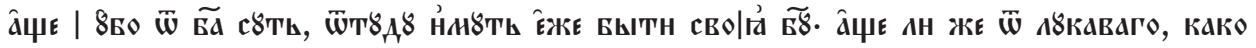

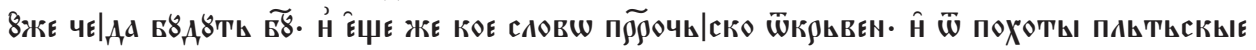

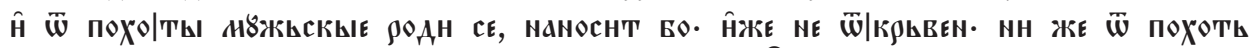

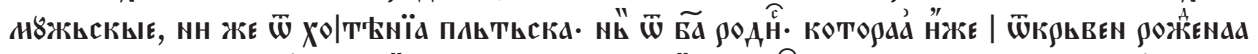

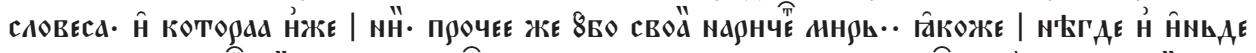

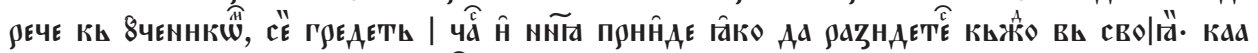

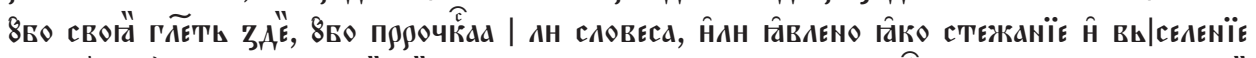

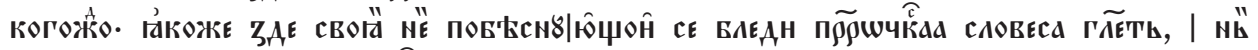

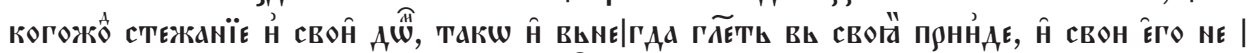

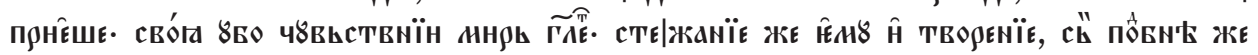

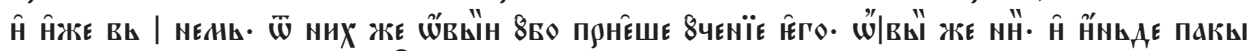

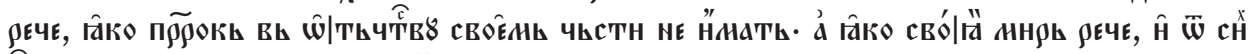

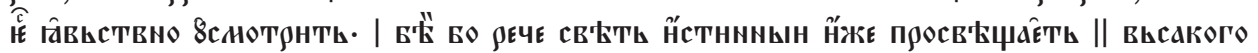

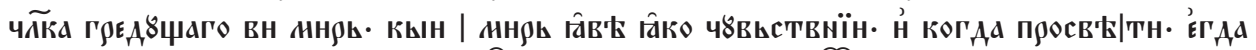

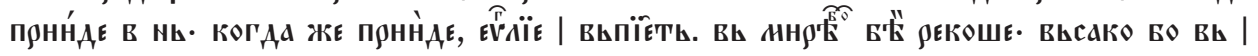




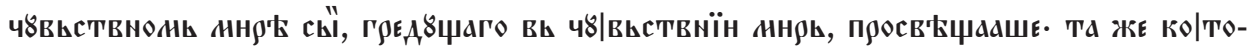

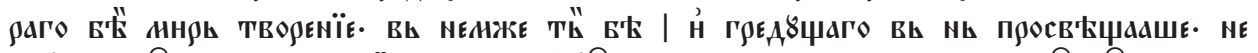

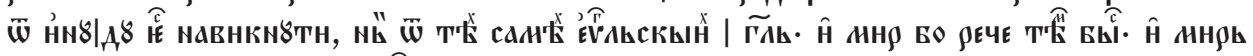

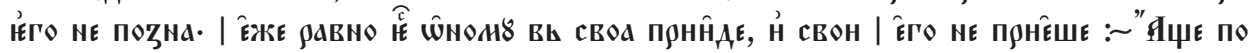
ъЕНАЬNAа с⿱艹

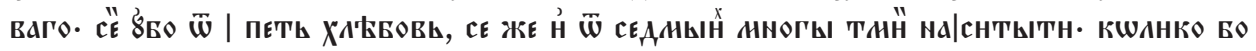

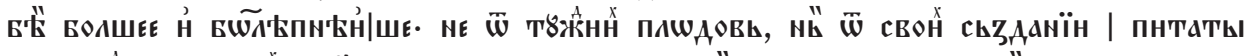

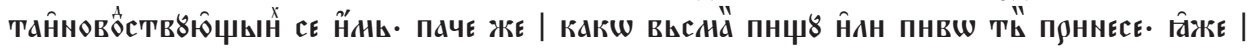

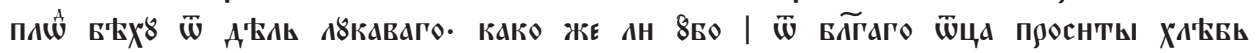

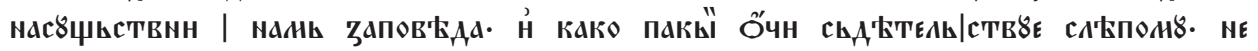

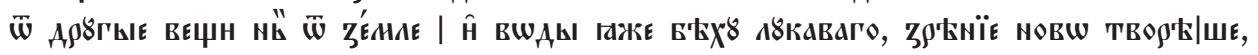

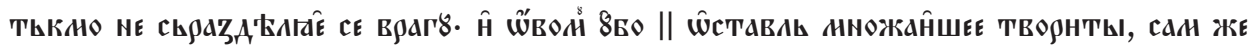

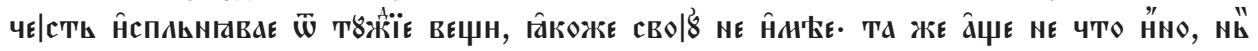

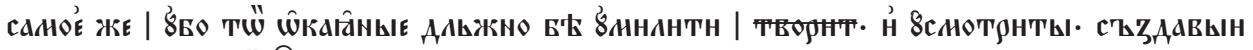

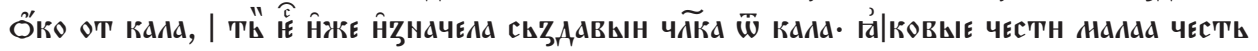

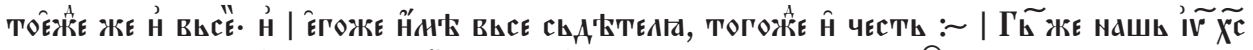

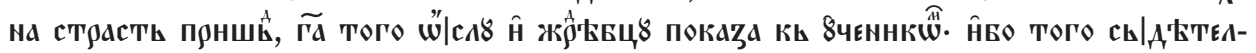

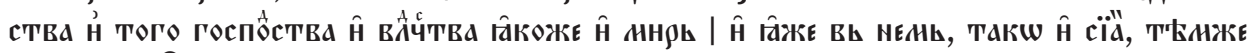

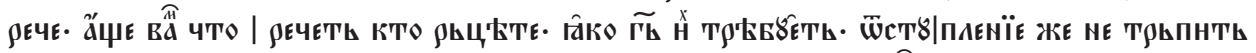

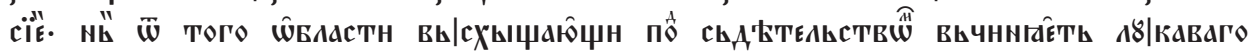

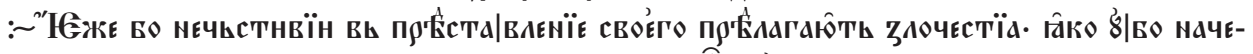

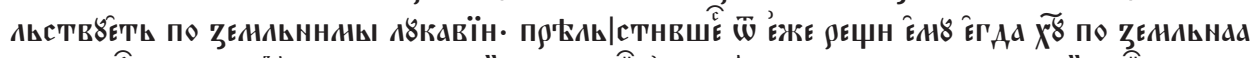

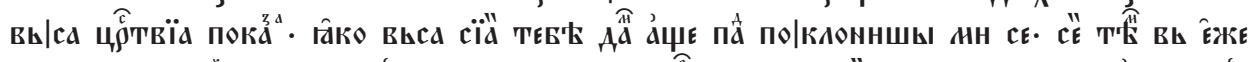

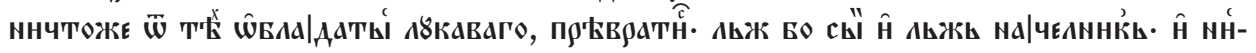

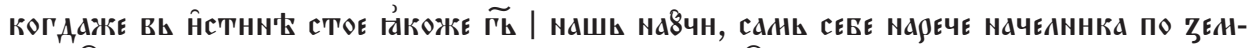

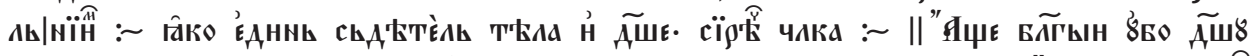

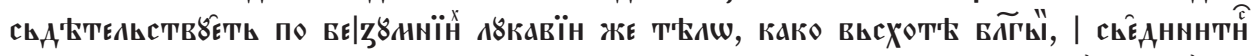

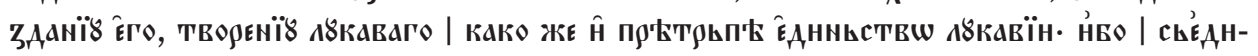

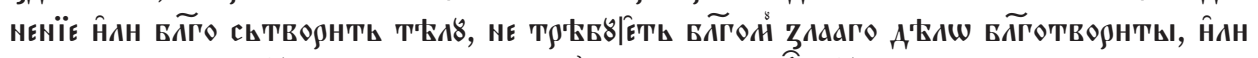

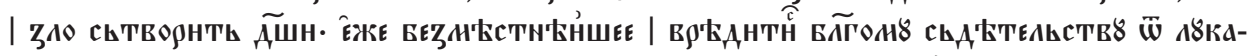

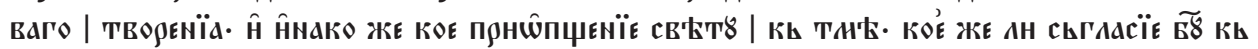

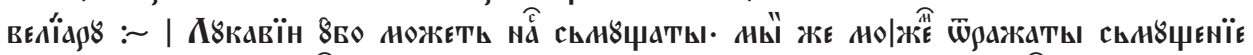

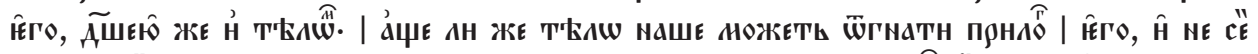

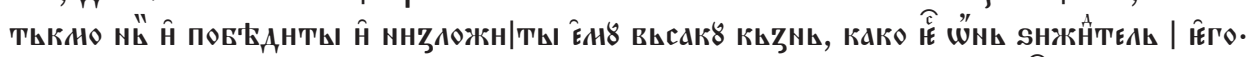

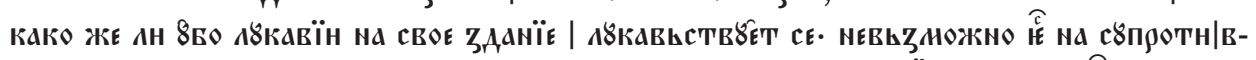

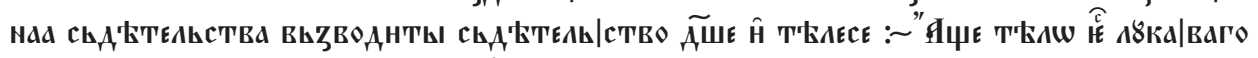

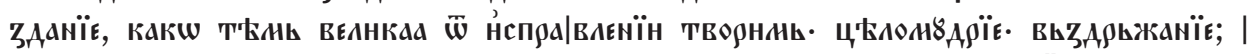

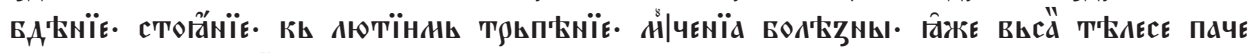

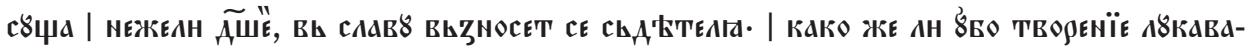
ro, A'TETT II 
ff. $308 v-309 r$

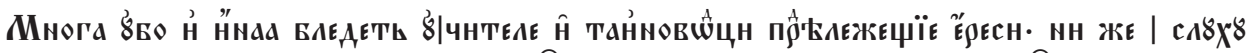

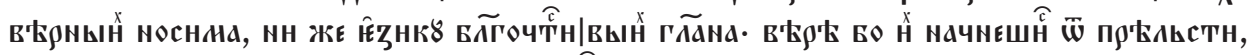

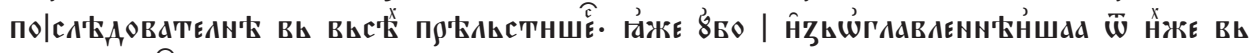

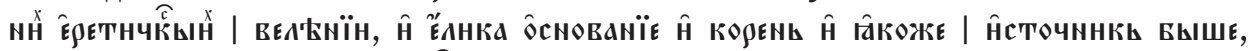

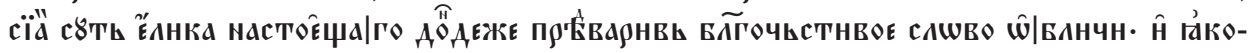

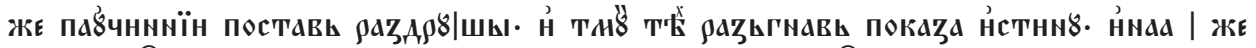
ш̈ставншЕ

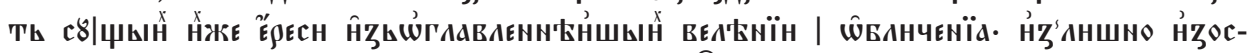

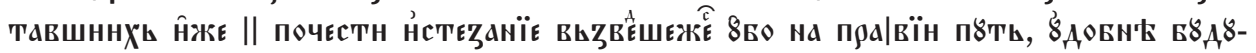

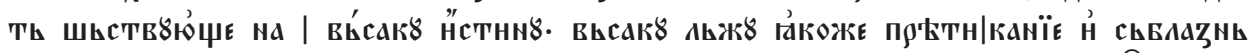

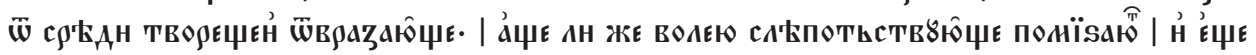

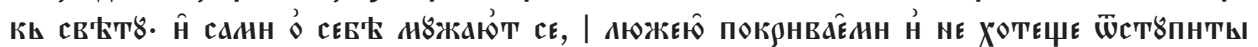

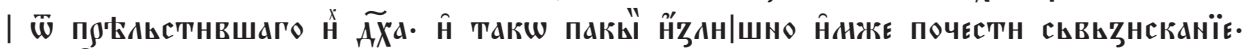

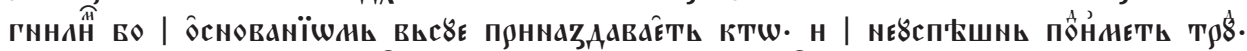

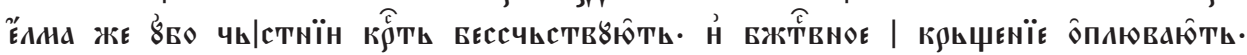

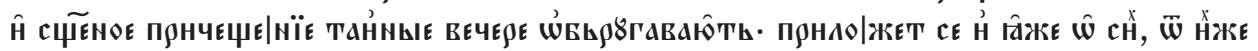

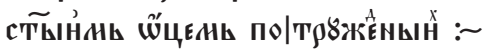

\section{Bibliography}

\section{Sources}

Božilov I., Totomanova A., Biljarski I., Borilov sinodik. Izdanie i prevod, Sofija 2010.

Euthymius Zigabenos, Panoplia Dogmatica, [in:] PG, vol. CXXX, col. 1189-1243.

Petrus Siculus, Historia Manichaeorum, [in:] PG, vol. CIV, col. 1239-1304.

Petrus Siculus, Sermo I-II adversus Manichaeos, [in:] PG, vol. CIV, col. 1305-1346.

Pнотіus, Contra Manichaeos, [in:] PG, vol. CII, col. 15-264.

Zakonopravilo ili Nomokanon svetoga Save. Ilovički prepis 1262 g., ed. M. Petrović, Gornji Milanovac 1991.

\section{Secondary Literature}

AваDžıeva M., Ezikăt na pavlikjanskata knižnina ot XVIII v., “Български език” / "Bălgarski ezik” 40, 2013, Supplement, p. 262-274.

Angold M., Church and Society in Byzantium under the Komnenoi, 1081-1261, Cambridge 2000.

Astruc Ch., Conus-Wolska W., Gouillard J., Lemerle P., Papachryssanthou I., Paramelle J., Les sources grecques pour l'histoire des Pauliciens d'Asie Mineure, "Travaux et mémoires du Centre de recherches d'histoire et civilisation byzantines" 4, 1970.

Bartiкjan R.M., Petr Sicilijski i ego "Istorija pavlikian”, “Византийский временник” / "Vizantijskij vremennik" 43.18, 1961, p. 323-358. 
Bartikjan R.M., Vizantijskaja, armjanskaja i bolgarskaja legendy o proischoždenii pavlikian $i$ ich istoričeskaja osnova, "Byzantinobulgarica" 6, 1980, p. 61.

Bălgarski etimologičen rečnik, vol. IV, Sofija 1995.

Berke M., An annotated edition of Euthimios Zigabenos, Panoplia Dogmatikē, Chapters 23-28, Belfast 2011.

Christian Dualist Heresies in the Byzantine World c. 650 - c. 1450, ed. J. Hamilton, B. Hamilton, Y. Stoyanov, Manchester 1998.

Delehaye H., Les légendes hagiographiques, Paris² 1906.

Dimitrova M., Knižninata na bălgarite katolici, [in:] Istorija na bălgarskata srednovekovna literatura, ed. A. Miltenova et al., Sofija 2008, p. 744-752.

Dokumenti za katoličeskata dejnost prez XVII v., Sofija 1993.

Duvernoy J., Les noms et la chose, "Slavica Occitania" 16, 2003, p. 189-198.

FermendžIn E., Acta Bulgariae Ecclesiastica. Ab a. 1565 usque ad a. 1799, Zagrebiae 1887.

Ficker G., Die Phundagiagiten. Ein Beitrag zur Sektengeschichte des byzantinischen Mittelalters, Leipzig 1908.

GaGova N., Edin verojaten prevodačeski autograf ot părvata četvărt na XV v. (Ošte vednăž za rannija slavjanski prevod na "Dogmatičesko vseorăžie" na Evtimij Zigavin), "Palaeobulgarica" 25.1, 2001, p. 79-94.

Gagova N., Porăčval li e despot Stefan Lazarevič prevoda na "Dogmatičesko vseorăžie" ot Evtimij Zigavin, [in:] EADEM, Vladeteli i knigi. Učastieto na južnoslavjanskija vladetel v proizvodstvoto i upotrebata na knigi prez Srednovekovieto (IX-XV v.): recepcijata na vizantijskija model, Sofija 2010, p. 130-140.

Garsoian N.S., The Paulician Heresy. A Study of the Origin and Development of Paulicianism in Armenia and the Eastern Provinces of the Byzantine Empire, Hague-Paris 1967.

GeČEva K., Bogomilstvoto i negovoto otraženie v srednovekovna hristijanska Evropa. Bibliografija, Sofija 2007.

Georgiev L., Bălgarite katolici v Transilvanija i Banat XVIII-părvata polovina na XIX, Sofija 2010.

GouIllard J., L'hérésie dans l'Empire byzantin jusqu'au XII siècle, “Travaux et mémoires du Centre de recherches d'histoire et civilisation byzantines" 1, 1965, p. 299-324.

Ivanov J., Proizhod na pavlikjanite spored dva bălgarski răkopisa, [in:] Izbrani proizvedenija, vol. I, Sofija 1992, p. 111-123.

Ivanova K., O slavjanskom perevode Panoplii dogmatyki Evfimija Zigavina, [in:] Issledovanija po drevnej i novom literature, Leningrad 1987, p. 101-105.

Jovкоv M., Pavlikjani i pavlikjanski selišta v bălgarskite zemi XV-XVIII v., Sofija 1991.

Kitanova M., “Čuždite” deca v bălgarskata kultura i ezik, “Български език” / "Bălgarski ezik” 61.3, 2014, p. 19-32.

Lemerle P., L'Histoire des Pauliciens d'Asie Mineure d'après les sources grecques, “Travaux et mémoires du Centre de recherches d'histoire et civilisation byzantines" 5, 1973, p. 1-144.

Miladinova N., Panoplia Dogmatike - a study on the antiheretical anthology of Euthimios Zigabenos in the Post-Byzantine Period, Leuven-Budapest 2010.

MiLETič L., Našite pavlikjani, “Сборник за народни умотворения, наука и култура” / "Sbornik za narodni umotvorenija, nauka i kultura” 19, 1903. 
Miltenova A., Otnovo za razkaza za proizhoda na pavlikjanite, "Bulgaria Medievalis" 6, 2015, p. 233-240.

Miltenova A., Razobličenieto na djavola-gramatik. (Kăm istorijata na starobălgarskata legenda za proizhoda na pavlikjanite), [in:] Čovek i vreme. Sbornik s naučni izsledvanija v pamet na Sabina Beljaeva, ed. R. Damjanova, E. Trajkova, Sofija 1997, p. 287-294.

NedelČEv M., Dialekt na bălgarite katolici (severen pavlikjanski govor), Veliko Tărnovo 1994.

Panaitescu P.P., Manuscrisele slave din Biblioteca Academiei RPR, vol. I, Bucureşti 1959.

PetKanova D., Narodnoto četivo prez XVI-XVIII v., Sofija 1990.

Popovski J., Thompson F., Veder W., The Troickiy sbornik (cod. Moskva, GBL, F.304, Troice-Sergieva lavra N 12). Text in transcription, "Полата кънигописьная" / "Polata Knigopisnaja. A Journal Devoted to the Study of Early Slavic Books, Texts and Literature" 21/22, 1988.

Pravilata na svetata Pravoslavna cărkva s tălkovanijata im, ed. S. Cankov, I. Stefanov, P. Canev, vol. I, Sofija 1912.

Radeva D., Pavlikjani i pavlikjanstvo v bălgarskite zemi. Arhetip i povtorenija VII-XVII v., Sofija 2015.

Rigo A., La Panoplia Dogmatica d'Euthymios Zygabenos. Savoir Encyclopédique et les Hérésies du Présent, [in :] Papers presented at the $19^{\text {th }}$ Annual Theological Conference of St. Tikhon's Orthodox University, Moscow 2008.

Rigo A., La panoplie dogmatique d'Euthyme Zigabène: les Pères de l'Église, l'empereur et les hérésies du present, [in:] Byzantine theologians. The systematization of their own doctrine and their perception of foreign doctrines, ed. A. Rigo, P. Ermilov, Rome 2009, p. 19-32.

Sharf A., Byzantine Orthodoxy and the "Preliminary fast" of the Armenians, [in:] Byzance. Hommage à André Stratos, vol. 2, Théologie et Philologie, Athènes 1986, p. 669-670.

Slovar' drevnerusskogo jazyka, vol. VII, Moskva 1980; vol. XIV, Moskva 1988.

STANČEV K., Literaturata na bălgarite katolici prez XVII i XVIII v. i prehodăt ot Srednovekovie kăm Văzraždane, “Литературна мисъл" / "Literaturna misăl” 3, 1981, p. 3-11.

StANČEv K., Pavlikjanite - učenici na djavola. Beležki otnosno finala na apokrifnija rozkaz za proizhoda na pavlikjanite, [in:] Vis et Sapientia. Studia in honorem Anisavae Miltenova, ed. A. ANGUsheva, M. Dimitrova et al., Sofija 2016, p. 761-768.

Średniowieczne herezje dualistyczne na Bałkanach. Źródła słowiańskie, ed. G. Minczew, M. SKowroNEK, J.M. Wolski, Łódź 2015 [= Series Ceranea, 1].

Tsıbranska-Kostova M., Pokajnata knižnina na Bălgarskoto srednovekovie IX-XVIII v. (ezikovo-tekstologični i kulturologični aspekti), Sofija 2011, p. 259-380.

Tsibranska-Kostova M., Raykova M., Les Bogomiles et (devant la Loi). Les sources slaves de droit canonique à propos de l'hérésie aux XIV-XV ss., "Revue des études sud-est européennes" 49.1, 2011, p. 15-33.

Vasiljev L., Grozdanović-Pajić M., Jovanović-Stipčević B., Novo datiranje srpskih rukopisa u Biblioteci rumunske akademije nauka, “Археографски прилози” / "Arheografski prilozi” 2, 1980 , p. 56, № 60.

Vendina T.I., Srednevekovyj čelovek v zerkale staroslavjanskogo języka, Moskva 2012.

Vrajkova-Genova E., Belene. Govor na pavlikjanite katolici, Pleven 2003.

Walczak-MiкoŁajczakowa M., Piśmiennictwo katolickie w Bułgarii, Poznań 2004.

Wickert J., Die Panoplia Dogmatica des Euthymios Zigabenos, Berlin 1910. 
Wolski J.M., Autoproscoptae, Bogomils and Massalians in the $14^{\text {th }}$ Century Bulgaria, "Studia Ceranea. Journal of the Waldemar Ceran Research Centre for the History and Culture of the Mediterranean Area and South-East Europe" 4, 2014, p. 233-244.

Wolski J.M., Bogomilite i svetlinata na Žitieto na sv. Ilarion Măglenski ot patriarh Evtimij Tărnovski, "Palaeobulgarica" 37.4, 2013, p. 74-81.

Zepos I., Zepos P., Jus Graecoromanum, vol. II, Leges imperatorum Isaurorum et Macedonum, Athen 1931 [= Aalen 1962].

Zlatanov I., Legurska P., Obrečeni na malcinstvo, “Дзяло” / “Dzjalo” 2.4, 2014.

\begin{abstract}
The paper compares how Paulicians were described in different types of medieval Slavonic sources by using the approach of the linguistic and culturological conceptualization of the alterity. By means of linguistic analysis, it tries to reach some essential dogmatic issues in the Paulician doctrine, and to focalize on the perception models towards Paulicians with their tangible semantic codes according to the specificities of the medieval world view. The two chosen texts the analysis is based on, are the legendary Bulgarian narrative Sermon about how the Paulicians have been conceived, and the Slavonic translation of $24^{\text {th }}$ title of Panoplia Dogmatica by Euthymius Zigabenus. The analysis is followed by an English translation of the Sermon (insofar known in 8 copies), and a partial edition of the Slavonic translation of Zigabenus's work upon the unique copy from the manuscript BAR 296, Library of the Romanian Academy of Sciences in Bucharest, dated between 1410-1420. The text account from the Slavonic manuscript is published for the first time, giving supplementary details about the overall Slavonic translation.
\end{abstract}

Keywords: Slavonic translation of Panoplia Dogmatica, Paulicians, Ms. slav. BAR 296

Mariyana Tsibranska-Kostova

Institute of Bulgarian language "Prof. L. Andreychin"

Bulgarian Academy of Sciences

Sofia 1113, № 53 Shipchenski prohod blvd., bl. 17

m.tsibranska@gmail.com 